\title{
Understanding writing curriculum innovation in Grades 7-12 in Chile: Linking teachers' beliefs and practices
}

\author{
Magdalena Flores-Ferrés ${ }^{1}$, Daphne van Weijen ${ }^{2}$ \& Gert Rijlaarsdam² \\ ${ }^{1}$ Independent researcher | Chile \\ 2 University of Amsterdam | The Netherlands
}

\begin{abstract}
This study aimed to provide evidence for continuing the innovation of writing instruction in Grades 7-12 of Chilean public schools. Teachers' beliefs influence their curricular interpretations; therefore, these beliefs play a key role when aiming for educational innovation. Hence, we investigated the relations between Language teachers' current practices of implementing the national curriculum and their beliefs regarding five paradigms of Language instruction. While beliefs on writing instruction are possibly embedded in beliefs on the broader topic of Language instruction, we took this broader category into account. We obtained 182 completed surveys from teachers of all Chilean regions (response rate: $47 \%$ ). Teachers reported a rather strong adherence to four curricular paradigms both in terms of practices and beliefs, while the fifth, the communicative paradigm, demonstrated a low level of adherence. The strength of the implementation of teachers' practices of writing instruction seemed to be related to teachers' beliefs, about writing and more general aspects as well. The results suggest that policymakers must focus public efforts on reinforcing teachers' beliefs regarding writing instruction, especially regarding communicative writing and on the connections between the five paradigms. In addition, we recommend that public efforts prioritize improvements in Grades 9-12 over Grades 7-8.
\end{abstract}

Keywords: Writing instruction, Beliefs, Secondary teachers, Curriculum, Spanish

\section{$\triangle$ journal of WRITING RESEARCH}

Flores-Ferrés, M., Van Weijen, D. \& Rijlaarsdam, G. (2022). Understanding writing curriculum innovation in Grades 7-12 in Chile: Linking teachers' beliefs and practices. Journal of Writing Research, 13(3), 367-414. https://doi.org/10.17239/jowr-2022.13.03.02

Contact: Magdalena Flores-Ferrés, independent researcher | Chile - magdflores@gmail.com Copyright: Earli | This article is published under Creative Commons AttributionNoncommercial-No Derivative Works 3.0 Unported license. 


\section{Introduction}

Society has increasingly become more complex and interconnected, mainly due to the advances of information and communication technologies and globalization (Leicht et al., 2018). Nowadays, people not only need to be able to receive and interpret information: they also need to be able to express their opinions, exchange views and discuss issues critically with others. As a result, communicative and writing skills have acquired a fundamental role in social participation (Flotts et al., 2016) and sustainable development (Leicht et al., 2018).

Consequently, countries are implementing public policies to develop future generations' writing skills (see Flotts et al., 2016; Graham \& Perin, 2007). To determine where efforts towards change should be directed, countries need to first gather evidence of current classroom practices (Flotts et al., 2016; Jesson \& Parr, 2019; Viennet \& Pont, 2017). As a result, descriptive studies about writing instruction in schools have been carried out in various countries (Graham, 2019; Graham \& Rijlaarsdam, 2016), including several survey-based studies which focused on teachers' role in writing instruction (e.g. Graham et al., 2013; Kiuhara et al., 2009; Veiga Simão et al., 2016).

During the last decade, Chile joined the international educational movement that emphasized the importance of acquiring writing skills. The government implemented educational public policies to promote quality writing instruction at school. Concretely, such policies corresponded to an incorporation of a writing test for students in Grade 6 (age 12) within the national assessment system (in Spanish, SIMCE), and a curricular reform, which resulted in poly-paradigmatic requirements for literacy and writing education (MINEDUC, 2012, 2013). The general framework of the Language curriculum for Grades 7 and above is now explicitly stated as being cultural and communicative (MINEDUC, 2013). Furthermore, the government reinforced the Writing subdomain (MINEDUC, 2012, 2013). It included key distinctions between genres, based on a macro-linguistic paradigm, and procedural and communicative features. In addition, the government explicitly positioned micro-linguistic features at the service of functional and procedural writing.

Chilean research centers have conducted descriptive studies about writing instruction in the classroom, which have mainly focused on primary education so far (Bañales et al., 2018; Bañales et al., 2020). Currently, research on upper grades is scarce (Flores-Ferrés et al., 2020). Therefore, a knowledge gap remains regarding what writing instruction currently looks like in Grades 7-12 of Chilean schools.

The current study is part of a larger project which aimed to describe teachers' writing instruction in Grades 7-12 of Chile (Flores-Ferrés et al., 2020). The project's aim was to provide an evidence base for future steps in the innovation of writing instruction in the country. We focused on teachers, due to their crucial role in providing quality education (Graham \& Rijlaarsdam, 2016; UNESCO, 2016; OECD, 
2018), and on public schools, due to our intention to contribute to equality in a strongly stratified educational system (Ávalos, 2016; Bellei et al., 2019). In Chile, students with less social opportunities tend to attend public education (Ávalos, 2016), which is mirrored by the distribution of teachers across school levels (Cabezas et al., 2017; Espinoza et al., 2020). In a previous study from this project, we reported teachers' practices and the contextual features (Flores-Ferrés et al., 2020) (See Figure 1: blocks 2 and 3). The current study extends this work by investigating teachers' beliefs, based on the key role they play in educational innovations (Clark \& Peterson, 1986, Kyriakides et al., 2009; Rietdijk et al., 2018) (Figure 1, block 1). We considered teachers' more general beliefs regarding their language and literacy instruction as well (Wang \& Matsumara, 2018; Troia et al., 2011).

This study could contribute to the ongoing efforts to implement new writing curricula, in Chile and other countries, by providing evidence about the current state of writing instruction in with reference to the outlines of the national curriculum for Grades 7-12, of public schools, in all of Chile's regions. In addition, this study is part of a growing body of studies on national surveys on writing instruction (e.g. Graham et al., 2013; Kiuhara et al., 2009; Veiga Simão et al., 2016). We expect to contribute to that set of studies by linking practices to teacher beliefs, and using the strengths of this links to interpret the quality of implementation of the new curriculum.

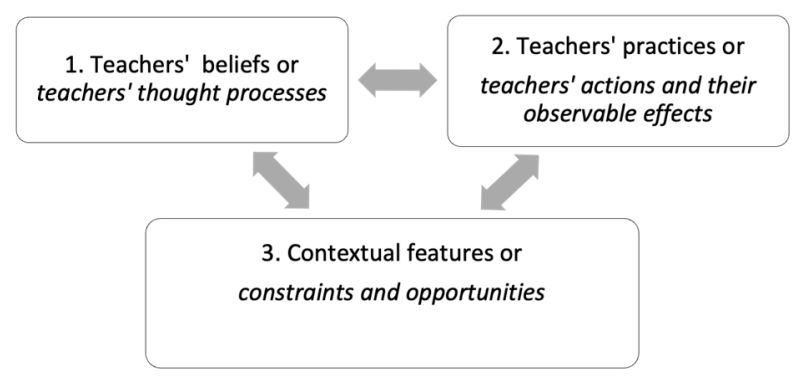

Figure 1: Relations between teachers' beliefs, teachers' practices, and contextual features of teachers' practices.

Note. Adapted from the Model of teacher thought and action (Clark \& Peterson, 1986).

\section{Interpretative framework}

\subsection{Grades 7-12 in Chile}

In Chile, Grades 7-12 belong to two different school systems: primary and secondary education (see Table 1). However, they share certain characteristics 
relevant to our study, such as the absence of a national writing test (Agencia Nacional de la Educación, n.d.) and the same curricular framework from Grades 7 to 10 (MINEDUC, 2013).

Nevertheless, contextual variations between Grades 7-8 and 9-12 in Chile seem to shape writing education in dissimilar ways (Flores-Ferrés et al., 2020). First, most teachers working in Grades 7-8 hold a general primary teaching degree, while the majority working in Grades 9-12 hold a teaching degree to specifically teach Language and Literature for secondary school students [in this paper, we refer to it as Language subject area, for readability issues]. Second, social and material conditions for teaching practice in secondary education appear to be harder than in primary education. This seems to be especially the case in urban settings, in which teachers face overwhelming working conditions, related to a high number of teaching hours, large group sizes, and challenging social conditions (Cornejo Chávez, 2009).

Table 1. The Chilean school system

\begin{tabular}{|c|c|c|c|c|c|}
\hline \multirow{3}{*}{$\begin{array}{l}\text { Educational } \\
\text { stage }\end{array}$} & \multirow{3}{*}{$\begin{array}{l}\text { Pre- } \\
\text { primary }\end{array}$} & \multicolumn{2}{|c|}{ Primary } & \multicolumn{2}{|r|}{ Secondary } \\
\hline & & & & & Scientific-humanistic or \\
\hline & & Lower & Upper & General & $\begin{array}{l}\text { Technical-professional } \\
\text { profile }\end{array}$ \\
\hline \multirow[t]{2}{*}{ Grades } & & $1^{\text {st }}-$ & $7^{\text {th }}-8^{\text {th }}$ & $9^{\text {th }}-10^{\text {th }}$ & $11^{\text {th }}-12^{\text {th }}$ \\
\hline & & $6^{\text {th }}$ & & & \\
\hline Age & $3-5$ & $6-11$ & $12-13$ & $14-15$ & $16-17$ \\
\hline
\end{tabular}

Note. Adapted from Santiago et al., 2013 (p. 15). In Chile, primary and secondary education are compulsory.

\subsection{Paradigms of writing instruction}

Paradigms are systems of beliefs that guide or constraint the actions of a community of practitioners (Guba, 1990; Kuhn, 1962). They do not represent absolute entities but are interrelated and evolve over time, because of variations in political, societal and ethical values (Sawyer \& Van de Ven, 2006; Ten Brinke, 1976) and also by the situated nature of teachers' practices (Graham \& Rijlaarsdam, 2016; Graham et al., 2002; Lipson et al., 2000; McCartey \& Mkhize, 2013).

First, the linguistic paradigms emphasize the acquisition of correct linguistic forms. They focus on the accuracy of language structures at two levels of the language system (Grabowski et al., 2018). The micro-linguistic paradigm focuses on the sentence or word level, and prioritizes the basic units of language, through grammar, vocabulary, and spelling. The macro-linguistic paradigm focuses on the 
textual level of the language system, prioritizing discourse structures, such as narrative and argumentative types of texts (MINEDUC, 2013).

Second, the cultural paradigm conceives the function of writing as a facilitator of human growth, academically and personally, and/or participating in the cultural community. Cultural writing can therefore take multiple forms. International studies typically recognize writing-to-learn, in which the act of writing aims to promote culturally or disciplinary shared knowledge (Klein \& Boscolo, 2016; Rijlaarsdam \& Braaksma, 2015), and writing for personal development, which emphasizes the act of writing for the development of creativity and personal expression (Nicholls, 2009).

The procedural paradigm considers writing as a skill. It is grounded in cognitive psychology (Flower \& Hayes, 1981; Hayes, 1996). It focuses on the writer's mind, which must learn to see the writing task as a communicative problem that has to be solved through decomposing the complexity of the writing process and to manage that process (Rijlaarsdam et al., 2009). This typically includes setting task goals and implementing strategies, for the process as a whole and for identifiable subprocesses, such as planning (generating, organizing ideas), formulating (translation ideas into language), and reviewing and revising (Rietdijk et al., 2017).

The communicative - or functional paradigm - prioritizes the suitability of language use for each communicative situation over its accuracy. This paradigm aims to promote writing for democratic and social purposes, which requires activating each member of a community and emphasizes the social context in which communication occurs. This entails acquiring communicative competence (Hymes, 1972), which, in turn, involves advanced linguistic and social skills (Moffett, 1983). As a result, students need to simultaneously assume both the writer's as well as the reader's perspective while they write (MINEDUC, 2013; see also Rijlaarsdam et al., 2008; 2009).

\subsection{Teachers' practices}

Teachers' practices correspond to what Clark and Peterson (1986) referred to as teachers' observable actions. They do not follow rational decision-making, tend to be interrelated entities, and tend to form patterns of actions (Kyriakides et al., 2009; Shulman, 1987). "Teachers demonstrate types of behavior that are based on different combinations of the various teaching approaches, which can be related to students' outcomes" (Kyriakides et al., 2009, p. 13). In writing education, we distinguish two observable practices: instructional and feedback practices.

Instructional practices refer to teachers' classroom actions, which can be associated with students' classroom behavior (Clark \& Peterson, 1986; Shulman, 1987). They are carried out to achieve certain learning goals, which are managed by the teacher (Sadler, 1989). Feedback practices refer to the information teachers provide to students, regarding the extent to which such learning goals have been 
achieved. Specifically, feedback is information given to students about the gap between their current level of performance and the level that they should aspire to achieve (Ramaprasad, 1983), which enables both the teacher and the students to adjust their teaching and learning processes (Graham et al., 2015; Moffett, 1983; Sadler, 1989).

In the past decade, some research efforts have been conducted in Chile to describe what writing instruction looks like in the classroom, mainly in primary education until Grade 6. Recently, one survey-based study gathered information from teachers working in Grades 4 to 6 from the 15 regions of the country (Bañales et al., 2020). Findings revealed that teachers implemented many evidence-based instructional and feedback practices in the classroom, which were recommended from international studies. $60 \%$ of teachers reported implementing a variety of those practices at least once a week (Bañales et al., 2020).

For their part, Gómez et al. (2016) collected information about writing instruction practices in Grades 5 and 6 of schools with good academic performance in the 2013 SIMCE exam. Their study involved various stages, and implemented mixed methods, including a stage in which they collected quantitative data from 117 schools. Students reported often receiving feedback regarding micro-linguistic aspects of the texts they wrote, while, by contrast, feedback regarding the content of the text or the development of ideas was less frequently received.

\subsection{Teachers' beliefs and their relations to teachers' practices}

Teachers' beliefs correspond to what Clark and Peterson (1986) called teachers' thought processes. They provide the psychological context in which teachers act, react, and guide their behavior by representing a battery of possible responses to the perceived task demands of their daily practice (Clark \& Peterson, 1986, p. 287). Thus, teachers' beliefs could exert considerable influence over the curriculum's implementation in the classroom, and, thereby over students' learning (Clark \& Peterson, 1986; Kyriakides et al., 2009). Consequently, "beliefs can be the single most important construct in educational research" (Pajares, 1992, p. 329). This is especially the case when aiming for educational innovation (Clark \& Peterson, 1986; Kyriakides et al., 2009; Rietdijk et al., 2018): it requires understanding how and to which extent changes in beliefs occur (Pajares, 1992, p. 329). In the present study, we consider two types of beliefs: teachers' self-efficacy beliefs and teachers' orientations.

Self-efficacy beliefs correspond to individuals' judgements of their own competence to execute a specific task in the future (Assaf et al., 2016; Pajares, 1992; Tschannen-Moran et al., 1998). Therefore, teachers' self-efficacy beliefs correspond to cognitive-evaluative beliefs, which are related to motivation (Holzerberg et al., 2014). Bandura (1977) placed these beliefs at the center of his socio-cognitive theory of human behavior, based on the notion of human agency. believing that 
individuals can exert control over their own personal actions, and thus, over their own lives (Zee \& Koomen, 2016). In this vein, attempts at educational innovation have generated a growing interest in self-efficacy beliefs, which are now considered to be one of the better predictors of human behavior (Bandura, 1986; TschannenMoran et al., 1998). Indeed, studies had shown positive relationships between teachers' self-efficacy and quality of instructional behavior (Holzberger et al., 2014).

A survey study conducted by Bañales et al. (2020) indicated that Chilean Language teachers working in grades 4-6 seem to feel moderately confident about their capacities to efficiently teach writing to their students. For upper grades, no studies are available about Chile.

Teachers' orientations correspond to teachers' underlying principles and assumptions about the nature of teaching and learning, which seem to guide their decisions during their practices (Lipson et al., 2000; McCarthey \& Mkhize, 2013; Wang \& Matsumara, 2018). Such orientations regarding writing instruction appear to be rooted in teachers' conceptions of teaching and learning in general (Lipson et al., 2000), and, more specifically, in their conceptions about literacy instruction (Graham et al., 2002; Wang \& Matsumara, 2018). They appear to be constantly evolving due to tensions between mother-tongue education paradigms, which are constantly changing (Sawyer \& Van de Ven, 2006; Ten Brinke, 1976).

Earlier studies have characterized literacy teachers' profiles into three main types (Lipson et al., 2000; Wang \& Mastumara, 2018). First, curricularist teachers tend to focus on teaching and learning micro-linguistic entities at the word or sentence level, which students need to acquire in order to subsequently explore meaning. Second, constructivist teachers generally emphasize inquiry-based or natural learning, because they believe that language development essentially requires language use in a social and meaningful interaction (Wang \& Matsumara, 2018). Third, some teachers appear to be mainly poly-paradigmatic (or eclectic) which means that they pick and combine elements from available approaches (Graham et al., 2002; Lipson et al., 2000; Wang \& Matsumara, 2018). However, the question is then to what extent they combine these elements from different paradigms into a new coherent paradigmatic approach of their own.

A review of recent literature revealed five studies that were conducted on Chilean teachers' orientations about writing instruction. The five studies were all small-scale involving between 3 - 6 teachers (Correa et al., 2013; Espinosa, 2018; Silva Peña et al., 2016) at various educational levels, from Grade 1 to 12, and/or covering only one school (Meneses, 2008; Silva Peña et al., 2016). Their outcomes provided signs suggesting that what teachers declare regarding paradigms seems to contradict what they apply in practice. Several studies pointed out the need to better understand key aspects of specific paradigms; the communicative (Espinosa, 2018; Flórez Petour, 2011; Silva Peña et al., 2016), the cultural (Silva Peña et al., 2016), and the procedural paradigms (Espinosa, 2018). Those paradigms seem to have been 
shaped on paper, as learning objectives in curriculum documents, but not systematically implemented in classroom practice. Instead, there seems to be some evidence of teachers placing greater emphasis on aspects which are less directly related to these paradigms, such as visual and motor writing skills (Silva Peña et al., 2016), norms and structure (Espinosa, 2018), knowledge transmission (Meneses, 2008; Silva Peña et al., 2016). An earlier observational study by Flórez Petour (2011) showed that while teachers demonstrated knowing the communicative curricular requirements, they tended to implement decontextualized writing tasks in the classroom.

These findings are consistent with international studies. Curricular modernizations do not happen overnight, and their implementation in real classrooms can vary (Graham \& Rijlaarsdam, 2016; Ten Brinke, 1976). In general, teachers guide their actions by deep-rooted beliefs which are difficult to change (Pajares, 1992). There is evidence from other countries indicating that curricular shifts towards constructivist paradigms may reach the classroom in a mechanical or formulaic way (Lipson et al., 2000). Other studies showed that contextual features may guide teachers to avoid the challenges of moving into new curricula. Teachers working with students from disadvantaged contexts may prefer to focus on teaching basic skills (McCartey \& Mkhize, 2013). Promoting advanced academic skills seems to be more difficult in schools attended by students from low-income families (OECD, 2019), which tends to be the case in Chilean public schools

\subsection{Teachers' generic beliefs regarding the Language subject area}

Writing instruction is embedded in the language lessons: beliefs about writing instruction relate to generic beliefs about language education. Teachers identify themselves as language teachers, not so much as writing teachers. We therefore distinguished three dimensions of language teachers' beliefs (Schiefele \& Shaffner, 2015; see also Shulman, 1987): the socio-educational, the pedagogical and the subject dimension.

The socio-educational dimension implies the skills needed to create a supportive learning environment (Ryan et al., 2015; Schiefele \& Shaffner, 2015; Von Suchodoletz et al., 2018), such as those required for classroom management, students' motivation and offering students affective support. The subject dimension corresponds to the teacher's understanding of the subject matter, e.g., for the language teacher, the knowledge of linguistics and literature. This understanding grows over time, with experience and relevant input. , and is needed to teach a particular subject effectively (Schiefele \& Shaffner, 2015; Shulman, 1987). The pedagogicaldimension corresponds to "the knowledge needed for teaching a specific subject and to make it comprehensible to others" (Schiefele \& Shaffner, 2015, p. 160), which can be understood as the most characteristic dimension of teachers' work (Shulman, 1987). It allows teachers to effectively represent, 
communicate and adapt the topics and issues of the subject-matter for their students, given their interests, abilities and level of cognitive development (Shulman, 1987, p. 8). It includes knowledge related to instructional design, and specially for the case of Language teachers, knowledge regarding reading and writing instruction, among others.

Some studies indicate that, in Chile, teacher preparation centers prioritize the transmission of content knowledge (Bustos Balladares, 2019), and give less relevance to other dimensions of teachers' work. This means that teachers' profiles do not seem to adequately respond to the socio-educational needs of their classroom (Ávalos, 2016; Bustos Balladares, 2019; Cox et al., 2014). Regarding language instruction, previous studies provide signs regarding teachers' knowledge of curricular requirements (see Flórez Petour, 2011). However, teachers seem to lack the pedagogical knowledge and skills to implement some of those requirements. In addition, there are signs indicating that teachers' pedagogical knowledge and skills about writing instruction seems to be stronger in primary education than in upper grades (see Bañales et al., 2020; Flores-Ferrés et al., 2020).

\section{Aims and research questions}

Our study intended to provide insight into teachers' adherence to the domainspecific paradigms of language instruction that have been promoted in Chile during the three last decades. By teachers' adherence to paradigms we understand their implementation of related practices (instructional and feedback practices) and adherence to related beliefs (orientations and self-efficacy beliefs). However, teachers' adherence to beliefs is not directly observable. To overcome this challenge, we aimed to obtain insight into each paradigm's internal coherence.

The more and stronger the relations between practices and beliefs within a certain paradigm, based on teachers' self-reports, the more coherent that paradigm would be, as represented in Figure 2. This would mean that teachers prioritize and feel confident regarding the same aspects of writing instruction, and that teachers' practices are in alignment with their beliefs. The coherence of a paradigm is determined by the number of relationships present between all components we distinguish (See Figure 2). That is, within the belief component (between orientations and self-efficacy beliefs -relation A), within the practice component (between instructional and feedback practices relation $B$ ), and between each of the two belief components with each of the two practice components (C-D-E-F in Figure 2). 
Finally, teachers' domain specific beliefs regarding writing instruction are rooted in their conceptions about literacy instruction (Graham et al., 2002; Wang \& Matsumara, 2018), and general pedagogic processes (Lipson et al., 2000), and, more specifically, in their conceptions about literacy instruction. That is why we investigated teachers' self-efficacy beliefs regarding the socio-educational dimension, the subject dimension and the pedagogic dimension of their Language practice, and the relationships between them and their domain specific beliefs about writing instruction (This is not represented in Figure 2).

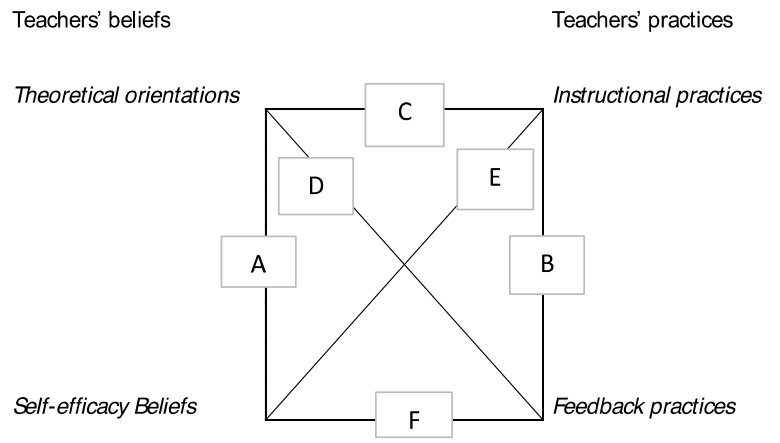

Figure 2: Overview of Relations between teachers' beliefs (A), practices (B) and between practices and beliefs (C-F).

Based on the above, we formulated three research questions:

1. To what extent do teachers adhere to the beliefs and practices of the prescribed domain-specific paradigms?

2. To what extent is teachers' adherence to each of the paradigms' beliefs and practices internally coherent? (see Figure 2)

3. To what extent do generic self-efficacy beliefs on the pedagogic, socioeducational and subject dimensions of Language instruction explain variations in teachers' adherence to and internal coherence of domain specific paradigms?

Given the substantial differences between Grades 7-8 and Grades 9-12 (FloresFerrés et al., 2020) we also investigated possible disparities between educational levels for each research question, which we will report on if found to be significant. 


\section{Method}

To collect data from teachers from all regions of Chile, we set up a nationwide survey study (see Flores-Ferrés et al., 2020). Using self-reports has been shown to be a valid method to describe teachers' teaching practices: previous self-reports made by teachers of literacy instruction have been corroborated by observational studies conducted in the classroom (Cutler \& Graham, 2008).

\subsection{Survey design}

We grounded our survey design on the social exchange theory (Dillman et al., 2014), which states that, when designing a survey study, it is crucial to maximize respondents' benefits and minimize the costs related to their responses. To do so, we ensured that the questionnaire directly addressed its audience and goal to increase respondents' engagement (Dillman et al., 2014; Rosenfeld et al., 2015). We explicitly informed participants about the objectives of the study, offered them compensation for their efforts - in the form of free books and certificates of participation - and created a safe environment for their responses, by implementing an online and self-administrated survey (Rosenfeld et al., 2015).

The questionnaire was designed through an iterative process which alternated between design and evaluation stages (see Flores-Ferrés et al., 2020). Each design stage was followed by an evaluation stage, which in turn led to the adjustment and improvement of the questionnaire. The evaluation consisted of the following steps: (1) The item designs were discussed with the research team of our institute; (2) the instrument was reviewed by nine Chilean knowledgeable professionals of Language and Writing, and then, (3) tried out by six L1 teachers, two Dutch and four Chileans. Finally, (4) it was evaluated by two Chilean teachers of Language using the think aloud method.

The questionnaire aimed to measure teachers' adherence to the five paradigms that were prescribed in the national curriculum (MINEDUC, 2013): the micro and the macro linguistic paradigm, and the cultural, procedural, and communicative paradigm. For each paradigm we included questions about instructional and feedback practices that were indicative for a specific paradigm and questions about theoretical orientations and self-efficacy (see Tables A1, in Appendix A, and C1, C2 and $\mathrm{C} 3$ in Appendix C).

We first collected information regarding teachers' instructional practices (RQ2, see Figure 2). For example, we asked teachers to indicate how frequently they instructed their students to plan the texts they had to write, which corresponded to the procedural paradigm. In second place, we collected information regarding teachers' feedback practices (RQ 2, see Figure 2). We included the following cluster question: "On what aspects of writing do students often receive more feedback? Please select the appropriate option (s). You can select more than one". Teachers 
had the option to select spelling, grammar, personal expression, identity development, among others.

In third place, we included one cluster asking about teachers' orientations (RQ 2, see Figure 2): "How relevant are the following aspects for your writing lessons. Please drag each of them to the group that best suits you: Major relevance, Minor relevance, No relevance". Teachers had the option to select grammar, textual organization, creativity, personal expression, from a total of 11 options. For detailed information about the items through which we asked about teachers 'self-efficacy beliefs, see Tables A1, in Appendix A, and C1 in Appendix C.

In fourth place, we included one cluster to gather information regarding teachers' domain-specific self-efficacy beliefs (RQ 2, see Figure 2): "The following is a list of possible objectives for a writing lesson. Please select those for which you feel most confident. You can select more than one". Respondents had choice from eight items, each representing one of the five domain-specific paradigms. For example, one of the options was: "To help my students develop their ideas while writing", which was related to the cultural paradigm.

We also included items asking about generic self-efficacy beliefs. We included questions to cover the three dimensions of Language instruction: from the pedagogical, subject, and socio-educational dimension. "From the following aspects relevant to your classroom work, select the ones that you best master. You can select more than one". Respondents had choice from 13 items, each representing one of the three dimensions. For example, one of the options was: "students' motivation", which was related with the socio-educational dimension. For detailed information about the items through which we asked about teachers' self-efficacy beliefs, see Tables A1 in Appendix A, and C3 in Appendix C.

\subsection{Participants}

The survey was set up to collect input from Language subject area teachers working in Grades 7-12 of Chilean regular public schools, of whom there were 9.036 in the year that the survey was distributed (Centro de Estudios MINEDUC, 2017). We found no available database with teachers' contacts to distribute the survey across the country. Therefore, we had to set one up ourselves, and sample representativeness was confirmed through a posterior analysis.

Teachers' contacts were gathered through schools of the 56 provinces of the country ${ }^{2}, 145$ municipalities, and 6 universities. In total we collected 374 teachers' email addresses from all Chilean regions. We distributed our online questionnaire between May and June 2017 and sent out two reminders by email. We obtained 182 completed questionnaires ( $>=80 \%$ completion). This means that we obtained a $47 \%$ response rate, which represents a $90 \%$ confidence interval with $6 \%$ sample error, according to Qualtrics (https://www.qualtrics.com/blog/calculating-sample-size/). 
Our sample was representative of the teaching population of 2017 in many respects, according to Centro de Estudios MINEDUC (2017), in terms of respondents' geographical and gender distribution, various aspects of teachers' profiles - such as the number of years that their teacher training program lasted and some working conditions - such as their weekly Language hours and number of students per group (see Figure B1 and Table B1 in Appendix B). In some respects, the sample differed from the teaching population. Most of the respondents reported working at a school with a Scientific-Humanistic curriculum (70\%), and almost a third, at a school with a Technical-Professional curriculum, which is a wider gap than the national average in Chile (58\% - 42\%, respectively; Centro de Estudios MINEDUC, 2017). The sample seemed to be younger, less experienced and held higher professional degrees then the population.

\subsection{Data analysis}

\section{Constructing indicators}

To allow for posterior comparisons we transformed the various answer scales in our survey (5-point scales and other types) into proportions, ranging from $0-1$, to correct for different numbers of items per scale for 11 constructs (practices and beliefs) and the three generic self-efficacy scales, about Language instruction

To check the reliability for these 11 constructs in three steps. First, we calculated Cronbach's alpha reliability corrected for attenuation. Second, we removed certain items when reliability analyses demonstrated that the Cronbach's alpha of the construct would substantially increase by at least .10 or more by doing so (see Field, 2013, p. 711). Third, we estimated the reliability of the resulting items in a scale, reporting the median correlation between items with the Spearman-Brown Prophecy formula for a seven item scale ${ }^{2}$.

Within the domain-specific practices and beliefs, Instructional Communicative practices originally included four items. However, the lack of correlations between Instructional Communicative practices led us to only include one of the four items in our analysis, and to disregard the other three. We choose one item that best represented our -strict- definition of communicative writing, due to the urgent need to enable students to develop efficient communicative skills (Leicht et al., 2018). For that reason, we chose to include the item 'asking students to send their texts to a real addressee'. 
FLORES-FERRÉS · UNDERSTANDING WRITING CURRICULUM INNOVATION IN CHILE | 380

Table 2. Reliability indices of the domain-specific practices -Instructional Practices (IP) and Feedback practices (FP) - and beliefs - Theoretical orientations (TO) and Self-efficacy belief (SEB) - included in the survey

\begin{tabular}{|c|c|c|c|c|c|c|c|c|c|c|c|}
\hline \multirow[t]{4}{*}{ Grade } & \multirow[t]{4}{*}{ Component } & \multirow[t]{4}{*}{ Construct } & \multicolumn{9}{|c|}{ Specific: writing instruction } \\
\hline & & & \multicolumn{4}{|c|}{ Linguistic } & \multirow{2}{*}{\multicolumn{2}{|c|}{ Procedural }} & \multirow{2}{*}{\multicolumn{2}{|c|}{ Cultural }} & \multirow[t]{2}{*}{ Communicative } \\
\hline & & & \multicolumn{2}{|c|}{ Micro } & \multicolumn{2}{|c|}{ Macro } & & & & & \\
\hline & & & $\mathrm{N}$ & SB & $\mathrm{N}$ & SB & $\alpha$ & & $\mathrm{N}$ & SB & \\
\hline 7-12 & Beliefs & TO & 3 & .76 & & & & & 6 & .66 & \\
\hline \multirow[t]{3}{*}{ (All grades) } & & SEB & & & & & & & 4 & .61 & \\
\hline & Practice & IP & & * & $2 / 3$ & .76 & 7 & .76 & $3 / 4$ & .88 & \\
\hline & & FP & 3 & .69 & & & & & 5 & .54 & \\
\hline \multirow[t]{4}{*}{ 7-8 } & Beliefs & TO & & .76 & & & & & & .77 & \\
\hline & & SEB & & & & & & .75 & & .54 & \\
\hline & Practice & IP & & & & .77 & & & & .91 & \\
\hline & & FP & & .66 & & & & & & .58 & \\
\hline \multirow[t]{4}{*}{$9-12$} & Beliefs & TO & & .77 & & & & & & .71 & \\
\hline & & SEB & & & & & & .76 & & .56 & \\
\hline & Practice & IP & & $*$ & & .75 & & & & .86 & \\
\hline & & FP & & .69 & & & & & & .47 & \\
\hline
\end{tabular}

Note. (1) SB = Spearman-Brown. (2) The number of items is the same for all grades and for grades 7-8 and 9-12. (3) To increase each scale's reliability (higher Cronbach's alpha) we removed one item for the macro-linguistic IP and from the cultural IP. (4) Blank cells are empty because they include one item. (5) A Star $\left(^{*}\right)$ indicates a variable that was not included in the survey'. 
381 | JOURNAL OF WRITING RESEARCH

Table 3. Reliability indices of the general self-efficacy beliefs about Language instruction included in the survey (Spearman Brown)

\begin{tabular}{llll}
\hline \multirow{2}{*}{ Grades } & \multicolumn{3}{l}{ Dimension of teacher's beliefs } \\
\cline { 2 - 4 } & Nedagogic & $\begin{array}{l}\text { Socio- } \\
\text { educational }\end{array}$ & Subject \\
\hline N of items & 4 & 5 & 3 \\
(all grades) & .66 & .62 & .50 \\
$7-8$ & & & .61 \\
$9-12$ & .67 & .60 & .20 \\
\hline
\end{tabular}

Note. Spearman Brown analyses based on an estimation of a seven-item scale. ${ }^{2}$

In Table 3, the reliability index for the subject dimension may point to different conceptions in the two educational levels (Grades 7-8, and 9-12). The index is based on three items: literature knowledge, linguistic knowledge and communication knowledge. These items do not correlate in Grades 9-12. This means that, in upper grades, when teachers feel confident about their content knowledge regarding one category (e.g., literature), some teachers do, and other teacher do not seem to feel the same regarding another item. Therefore, we decided to analyze the relations between the subject dimension and domain specific beliefs in upper grades (Grades 9-12) for each of the three items separately.

\section{Analyzing the data}

Adherence. First, we conducted descriptive analyses by calculating the average scores for all variables. To evaluate respondents' adherence to domain-specific paradigms in terms of beliefs and practices (RQ1), we first created proportions 0-1, to homologate our scales. Secondly, we multiplied them by 100 , to obtain percentages. Thirdly, we set benchmarks which would allow us to better understand and communicate our results (Rietdijk et al., 2018, p. 10). On a scale from 0 to 100 , we defined a low leve/of adherence when the average adherence was $33 \%$ or less, and a high level of adherence when the average adherence was $66 \%$ or more. This meant that the average teacher in Chile adheres to this paradigm for $33 \%$ or for $66 \%$ percent.

Coherence. To describe domain-specific paradigms in terms of coherence (RQ2, see Figure 2) and the relations between teachers' domain specific beliefs with teachers' general self-efficacy beliefs about Language instruction (RQ3), we ran correlational analyses. 
Educational level. We ran multivariate analyses of variance to compare the results of RQ 3 by educational level: upper primary (Grades 7-8) and secondary education (Grades 9-12).

\section{Results}

\section{RQ1: Adherence to curricular paradigms}

In general, we found similar patterns of adherence to domain-specific paradigms across teachers' beliefs and practices (see Figure 3). The micro and macro-linguistic paradigms revealed the highest level of adherence to beliefs and practices, followed by the procedural paradigm. By contrast, the communicative paradigm revealed the lowest level of adherence: the average adherence was below $33 \%$ for almost all four beliefs and practices. Regarding teachers' reported adherence to beliefs, results in Figure 3 show that adherence was generally lower for Theoretical orientations than for Self-efficacy beliefs across paradigms, except for the Cultural paradigm, for which the reverse was the case.

Teachers' practice adherence to domain specific paradigms also revealed differences. Reported adherence to Instructional practices was generally high across all paradigms ${ }^{1}(68 \%-78 \%)$, except for the communicative paradigm (18\%). Teachers' reported adherence to Feedback practices was highest for the two linguistic paradigms (both, 66\%), and lower for the other three paradigms, especially the communicative one $(10 \%)$. Scores on theoretical orientations were similar across all paradigms, expect for the communicative paradigm which revealed the lowest adherence (29\%). Finally, teachers' self-efficacy beliefs were rather high for the macro-linguistic, micro-linguistic and procedural paradigms, but revealed to be lower for the cultural and communicative paradigms (45\% and 36\%, respectively) For detailed information about the obtained results, see Tables C1, C2 and $\mathrm{C} 3$ in Appendix C.

\section{RQ 2 Internal Coherence of the curricular paradigms}

The extent to which teachers adhered coherently to domain-specific paradigms is shown in Table 4. We observe three general trends. First, the two types of beliefs correlated significantly within almost all paradigms, which indicates that the more teachers adhered to theoretical orientations, the more they tended to do so for selfefficacy beliefs as well (Figure 2: A). Second, correlations between instructional and feedback practices were far less common than for beliefs. Only within the procedural and cultural paradigms the instruction and feedback correlates (Figure 2: B). Third, beliefs were generally significantly correlated with feedback practices (Figure 2: D \& F), especially in Grades 7-8, but rarely with instructional practices (Figure 2: C \& E) (see Table 4). 
With respect to the specific paradigms' internal coherence, our analyses revealed two main findings. First, the cultural paradigm revealed the highest number of significant correlations in both educational levels (5 out of 6 ). Second, the communicative paradigm was the least internally coherent of the five paradigms, with only two significant correlations between beliefs and feedback practices in Grades 7 -8 and none in Grades 9-12.

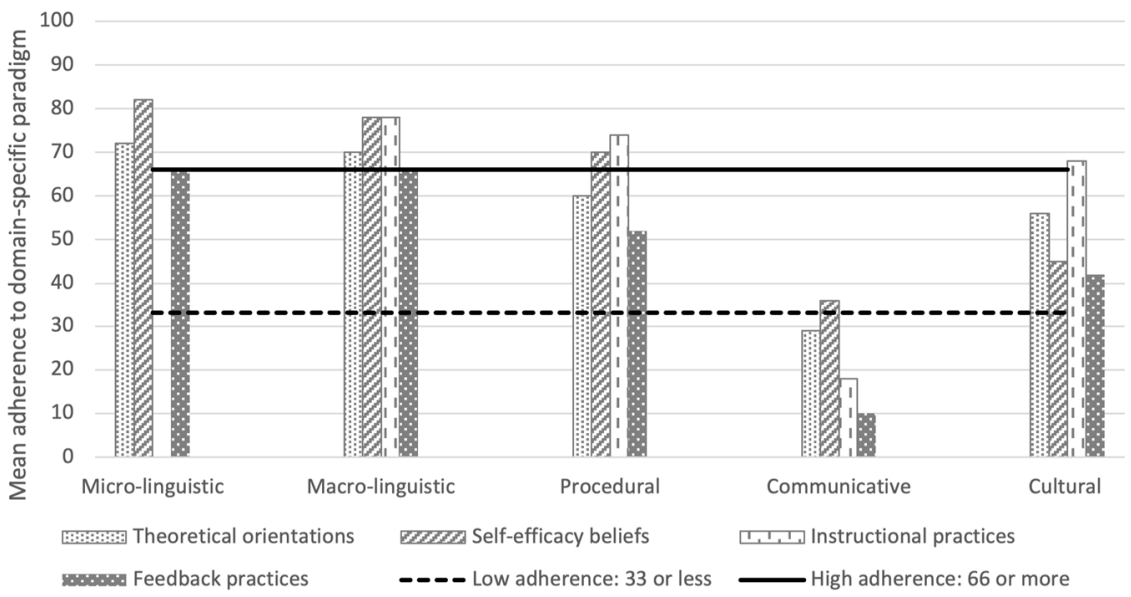

Figure 3. Mean percentages of adherence to domain-specific paradigms in terms of teachers' beliefs and practices.

\section{RQ 3 The role of generic beliefs}

We explored possible explanations for variations between the adherence to domain-specific paradigms by looking at their relationships with teachers' beliefs regarding more general requirements of their Language lessons.

First, we explored teachers' self-efficacy beliefs about general requirements for their Language instruction (Figure 4), regarding pedagogical, socio-educational and subject dimensions of teachers' practices and beliefs. This analysis revealed that the subject dimension was most adhered to on average $(M=70 \%, s d=25)$, while the pedagogical dimension showed the lowest average adherence $(M=50 \%, s d=29)$. This means that teachers tend to feel more confident regarding their subject (e.g., regarding language or literature), and less regarding their pedagogical skills such as writing instruction or oral communication instruction (see Figure 4). These outcomes could contribute to explaining why the cultural, macro-linguistic and micro-linguistic paradigms appeared to be rather strong in Chilean classroom, while on the other hand, the communicative paradigm appeared to be less strongly adhered to. For detailed information about the obtained results, see Table C3, in Appendix C. 
FLORES-FERRÉS • UNDERSTANDING WRITING CURRICULUM INNOVATION IN CHILE 384

Table 4. Coherence of curricular paradigms by educational level

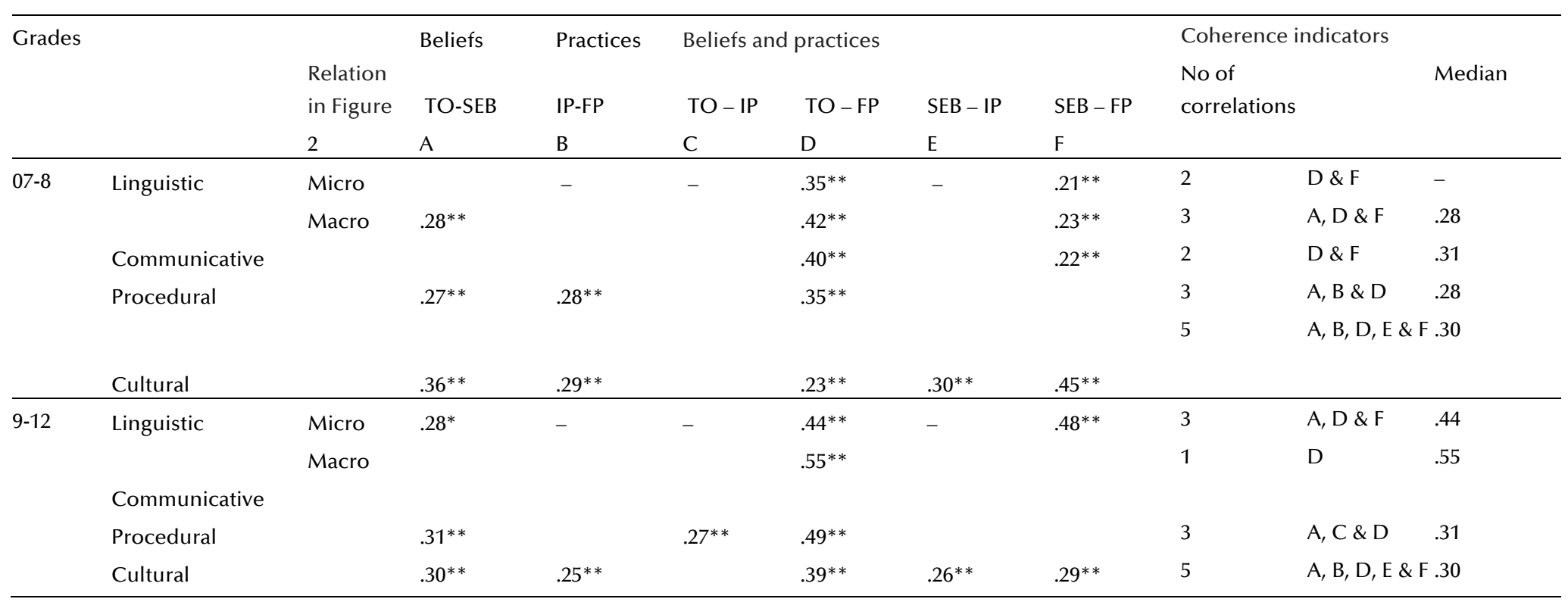

${ }^{*}$ Correlation is significant at the 0.05 level (2-tailed); ${ }^{* *}$ Correlation is significant at the 0.01 level (2-tailed). Non-significant correlations are not reported.

Note. $\mathrm{TO}=$ Theoretical beliefs; $\mathrm{SEB}=$ Self-efficacy beliefs; IP=Instructional practices; FP=Feedback practices. Grey columns = coherence indicators. Empty cells $=$ no significant correlation. Dash $(-)$ = correlation was not conducted, since our questionnaire did not include variables regarding micro linguistic instructional practices ${ }^{1}$. 
The overall difference by educational level revealed to be significant: $F(13,168)$ $=2.5, p=0.04$. On the one hand, self-efficacy beliefs regarding the socio-educational dimension were found to be stronger in Grades $7-8$ than in upper grades, $F(13,168)$ $=4,9, p=0.034$. Findings revealed that this was due to variations regarding two specific variables. In Grades 7-8, teachers tend to be more confident regarding their skills for classroom management and for students' motivation (see Table 5). On the other hand, self-efficacy beliefs regarding literature knowledge were found to be higher in Grades 9-12 (Table 5).

Second, we explored possible relationships between teachers' general beliefs about the Language subject area and their specific beliefs about writing instruction (see Table D1, Appendix D). Results revealed that the number of significant correlations in Grades 7-8 (30 out of 46) doubled those in Grades 9-12 (16 out of 46). This indicates that, mainly in Grades 7-8, the more confident teachers feel about general aspects of Language instruction, the more they seem to adhere to specific beliefs about writing instruction. This seems to be particularly the case for the cultural paradigm in Grades 7-8.

Table 5. Comparison of dimensions of teachers' self-efficacy beliefs by educational level: Grade 7-8 vs Grade 9-12

\begin{tabular}{|c|c|c|c|c|c|c|}
\hline \multirow[t]{2}{*}{ Dimension } & \multirow[t]{2}{*}{ Variable } & \multirow[b]{2}{*}{$F$} & \multirow[b]{2}{*}{$d f$} & \multirow[b]{2}{*}{$p$} & \multicolumn{2}{|c|}{$\begin{array}{l}\text { Percentage } \\
\text { of adherence } \\
\text { Grades }\end{array}$} \\
\hline & & & & & 7-8 & $9-12$ \\
\hline \multirow[t]{3}{*}{ Pedagogic } & Reading instruction & & & & & \\
\hline & Writing instruction & & & & & \\
\hline & $\begin{array}{l}\text { Oral communication } \\
\text { instruction }\end{array}$ & & & & & \\
\hline \multirow{5}{*}{$\begin{array}{l}\text { Socio- } \\
\text { educational }\end{array}$} & Classroom management & 5,547 & 1 & .020 & 75 & 59 \\
\hline & Students' motivation & 4,568 & 1 & .034 & 76 & 62 \\
\hline & Tutoring students & & & & & \\
\hline & Collaborative writing & & & & & \\
\hline & Differentiation & & & & & \\
\hline \multirow[t]{4}{*}{ Subject } & Literature knowledge & 13,918 & 1 & .000 & 53 & 79 \\
\hline & Language knowledge & & & & & \\
\hline & Communication & & & & & \\
\hline & knowledge & & & & & \\
\hline
\end{tabular}




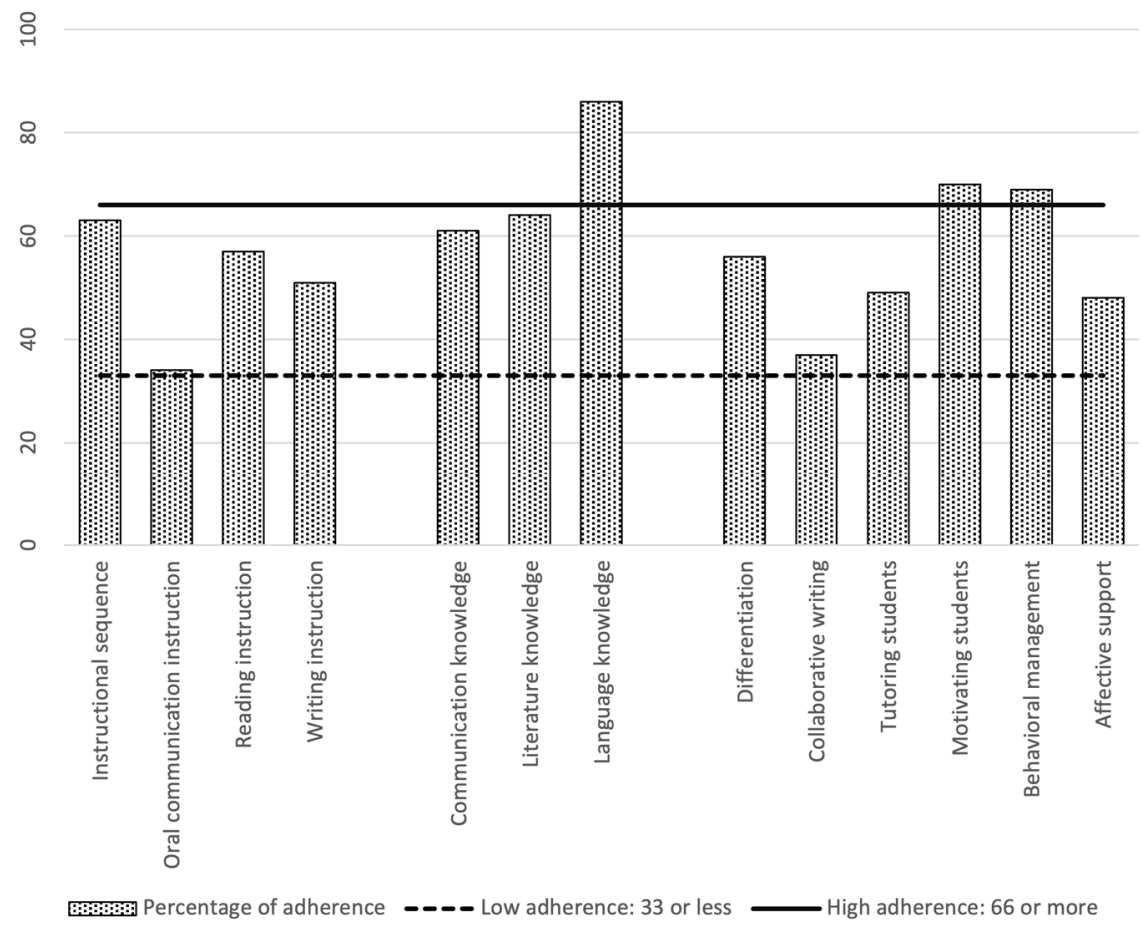

Figure 4. Mean percentages of adherence to general self-efficacy beliefs regarding Language instruction.

Note. (1) Empty cells mean that we did not find significant differences by educational level. (2) We report on individual items, since the subject dimension did not form a reliable scale in Grades 9-12 (see Table 3).

\section{Discussion}

Currently, there is a lack of information on how writing instruction is carried out in Grades 7-12 of Chilean public schools, which is the most fragile educational subsystem because of social segregation (Bellei et al., 2019). This information gap needs to be bridged to facilitate the development of public policies specifically suited to the needs of the system (Flotts et al., 2016; Viennet \& Pont, 2017). The latter requires responding to the needs of pupils from the most disadvantaged backgrounds (Assaf et al., 2016; Jesson \& Parr, 2019; Parr \& Limbrick, 2010; OECD, 2018).

We aimed to gain insight into teachers' adherence to the prescribed curricular paradigms of language instruction, which implied examining their internal coherence. To do so, we aimed to respond to the following research questions: 
- RQ1: To what extent do teachers adhere to the beliefs and practices of the prescribed domain-specific paradigms?

- RQ2: To what extent is teachers' adherence to each of the paradigms' beliefs and practices internally coherent? (see Figure 2)

- RQ3: To what extent do generic self-efficacy beliefs on the pedagogic, socioeducational and subject dimensions of Language instruction explain variations in teachers' adherence to and internal coherence of domain specific paradigms?

We start this section by, first, stating the limitations of the study. Second, we discuss our main findings. Third, based on the latter, we draw our conclusions. Finally, we close this section by formulating recommendations for policies and research aiming to reinforce writing instruction in Grades 7-12 of Chilean public schools.

\subsection{Limitations of this study}

Before we discuss the results per research question, we must point to some features of the study that must be considered when interpreting the results. First, the results stem from a survey study, with all kinds of possible biases. Second, there were theory driven examples of surveys that tried to validate instructional practices and beliefs within so-called domain specific paradigms.

Bias. To minimize the risk of sample biases, we put effort into ensuring the sample's representativeness. Fortunately, various sample features seemed to accurately represent the national teacher population. Post hoc analyses (see Figure B1 and Table B1 in Appendix B) revealed that respondents' geographical and gender-related distribution, and the percentage of schools with an Indigenous Language curriculum appeared to be representative of the Chilean teaching population (Programa de Educación Intercultural Bilingüe MINEDUC, 2017). However, some of our sample's features appeared to differ from those of the Chilean teaching population, although these were in general minor variations. First, our respondents' profiles revealed to be somewhat younger, with less years of experience and a higher level of professional degrees than indicated by the national data. This could be explained by the online digital distribution of the survey, a method which tends to appeal more to a younger demographic (Messer \& Dillman, 2011). Second, schools offering a Scientific-Humanistic curriculum for Grades 11-12 were overrepresented in our sample, compared to those offering a TechnicalProfessional curriculum. All in all, there are no signals that these factors would be related to differences in adherence to paradigms or to differences in coherence of the belief-practice relations.

A well-known source of bias is the social desirability of survey data, which might result in an overestimation of the level of adherence to paradigms reported. However, some of the results that we obtained seem to demonstrate that this was not the case. The communicative paradigm, which has been desirable for some 
decades, hardly received any support, a finding which is consistent with earlier Chilean studies (Flórez Petour, 2011; MINEDUC, 2009b).

Survey construction. First, constructing a questionnaire that aims to represent paradigms as prescribed in a national curriculum document instead of listing all possible practices could have been a study in itself. We now have generated and borrowed items and places them in a matrix (see section method) and could analyze the scales posterior. The quality of the scales varied. Whether items that did not fit in the scale point to an invalidation of the theory (the definitions of the paradigm in this country) or a true observation in the implementation of the paradigm (this instructional practice does not go along in this phase of implementation with another instructional practice that belongs to the same paradigm) is undecided.

A second issueabout the survey is the focus on frequency in the instructional practice and feedback items. early large scale studies this might be a first step to investigate whether practices are at least in operation (see Kyriakides et al., 2009). In our survey, we aimed to compensate for the narrow interpretation of frequency of practices by adding questions about beliefs. When teachers respond positively to theoretical orientations that underly instructional practices, and score relatively high on self-efficacy, this might be interpreted as qualitative support for the reported practices.

\subsection{Discussion of main findings}

\subsubsection{Adherence to domain-specific paradigms (RQ 1)}

Teachers reported rather high adherence to four of the five curricular paradigms prescribed in the Chilean national curriculum documents, in terms of practices and beliefs: micro-linguistic and macro-linguistic, the procedural and the cultural paradigm. However, low adherence was reported for the communicative paradigm (for all the four constructs we measured, regarding both practices and beliefs). These results seem consistent with what was reported in earlier studies about teachers' literacy practices in the Chilean context, in particular, about teachers' beliefs in primary education (Espinosa, 2018; Meneses, 2008) and teachers' practices in secondary education (Flórez Petour, 2011; MINEDUC, 2009b). The results also reflect international findings, such as a study in the Netherlands, based on interviews, observations, and questionnaires (Rietdijk et al., 2018). This led us to question ourselves: Why is the communicative paradigm not a priority in Chilean classroom? Is it difficult to implement? We recommend that further research should be conducted to clarify this issue, especially as communicative writing skills have become so important in contemporary society (Leicht et al., 2018). In addition, when aiming to strengthen writing instruction in Chile, we recommend reinforcing authentic communicative writing in the classroom. 


\subsubsection{Coherence within domain-specific paradigms (RQ 2)}

We aimed to indicate the internal coherence of each of the nationally prescribed paradigms, that is, to assess the relations between teachers' practices (instructional and feedback practices) and teachers' beliefs (orientations and self-efficacy beliefs) per paradigm. Paradigm coherence indicates that teachers prioritize and feel confident regarding the same aspects of writing instruction. Furthermore, it means teachers' practices relate to their beliefs, and therefore, teachers' practices are consistent in the classroom.

Of all the paradigms, the cultural paradigm was found to be the most internally coherent. By contrast, the communicative paradigm was clearly the least coherent. This finding suggests, first of all, that teachers' orientations do not seem to correspond to their self-efficacy beliefs about the communicative paradigm. Second, the lack of internal coherence suggests that when teachers implement a practice that we could label as communicative, it tends not to be guided by communicative beliefs. Third, teachers' instructional and feedback practices do not appear to be consistent in the classroom.

The communicative paradigm's lack of coherence seems to be in line with earlier Chilean studies (MINEDUC, 2009b; Flórez Petour, 2011) and international research (Rietdijk et al., 2018), which raises a worrying signal, as communicative skills are essential for successful participation in modern society (Leicht et al., 2018). It reinforces our previous conclusion: further research should be conducted to understand the weak implementation and coherence of the communicative paradigm. In addition, we recommend that administrative efforts should focus on developing Chilean Language subject area teachers' understanding and implementation of communicative writing in their classrooms, in combination with other paradigms.

We are fully aware that the results regarding the communicative paradigm may be affected by the item we chose as representative of the instructional Communicative practices: sending texts to a real addressee. During the analysis phase, the lack of correlations within the set of questions related to Communicative writing instruction forced us to select one representative item and disregard the others. The results of the study would have been different if we had selected another item: asking students to share their texts with their peers $(61 \%$ of teachers reported regularly implementing that practice, see Flores-Ferrés et al., 2020). However, we selected the item "sending texts to a real addressee" because among instructional communicative practices, this item was the one that best suited our definition of authentic communicative writing, which we understand only occurs "in the ultimate context of somebody-talking-to-somebody-else-about something" (Moffett, 1983, p. 5, see also Flores-Ferrés et al., 2020) . ${ }^{3}$ Furthermore, the low scores we obtained is consistent with previous findings regarding communicative writing in the classroom (MINEDUC, 2009b; Flórez Petour, 2011). 


\subsubsection{Correlations between practices and teachers' beliefs by domain specific paradigm (RQ 2)}

We found some similarities in the relationships between practices and beliefs, across all domain-specific paradigms. In all cases, instructional practices did not correlate with teachers' beliefs. Figure 5 provides a visual representation of the strength of the relationships between practices and beliefs. It is based on our model for measuring these relationships (Figure 2), and on the results obtained from our data. In general, orientations beliefs correlated with feedback practices (D), but instructional practices hardly correlated with orientations (C) or self-efficacy beliefs (E) at all (See also Table 4).

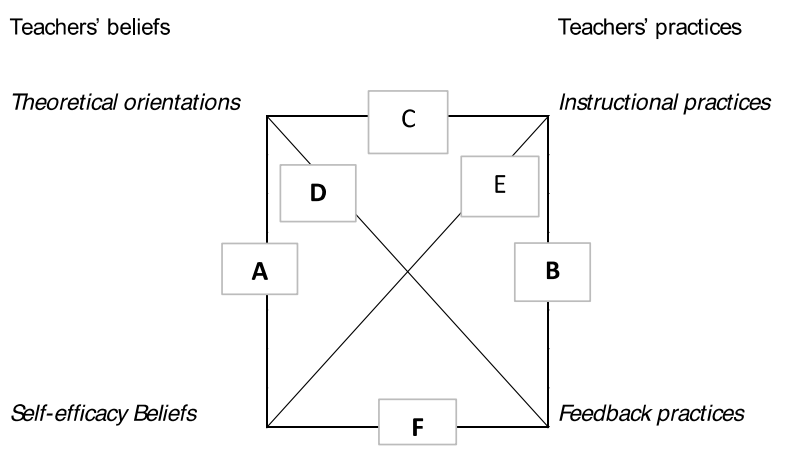

Figure 5. Visual representation of the strength of relations between teachers' beliefs and practices within paradigms. Bold font: moderate to strong relation. Grey font: weak to no relation.

This lack of associations between instructional practices and teachers' beliefs represents a major finding in this study. Nevertheless, it raises questions regarding how to interpret it. Relations F, A and D (bold), related to feedback, are stronger than relations $\mathrm{C}$ and $\mathrm{E}$ (grey), related to instructional practices. For example, the relation between self-efficacy beliefs and feedback practices is stronger than the relation between self-efficacy beliefs and instructional practices. The same holds for orientations.

We might first consider questioning the validity of measuring instructional features in terms of frequency. We examined teachers' practices by quantifying their frequency of occurrence, since frequency can function as a basic indicator of qualitative factors (Kyriakides et al., 2009, p. 14). We know that research centers from various countries are conducting survey-based studies that measure the frequency of implementation of teachers' practices of writing instruction (e.g. Bañales et al., 2020; Graham et al., 2013; Kiuhara et al., 2009; Veiga Simão et al., 2016). Some studies 
have been conducted to assure the validity of these self-reports methods (Cutler \& Graham, 2008).

As a second possibility, we may also consider that teachers' definition of what should be included within feedback practices is closer to the definition of the paradigm than their definition of instructional practices. The obtained outcomes mean that teachers seem to feel more confident about providing feedback based on domain-specific paradigms (for example, macro-linguistic paradigm) than leading instructional practices based on the same paradigm. Feedback practices regarding the micro-linguistic paradigm mainly corresponds to feedback on spelling, grammar, and vocabulary. But instructional practices regarding microlinguistic features may vary.

As a third possibility, we may consider that the differences in the strength of the correlations between beliefs with feedback practices (stronger), and beliefs with instructional practices (weaker) are due to the disparity between the contexts in which they are carried out. Working in a 'live' classroom setting requires teachers to act in a complex scenario. It requires teachers to be flexible because sometimes students behave in a certain way that requires teachers to change their lesson plans halfway through the lesson. In addition, teachers' practices are complex constructs which do not always follow rational decisions (Kyriakides et al., 2009; Shulman, 1987). It may be that, although teachers know how to address certain pedagogical goal in theory, their behavior follows a different path (see Florez Petour, 2011). A possible result might be that the lesson no longer adheres fully to the teacher's orientations. This may be due to the deep-rooted beliefs teachers hold regarding how to teach, which implies difficulties for educational innovation (Pajares, 1992).

\subsubsection{The role of teachers' general beliefs regarding Language instruction (RQ 3)}

Looking at the outcomes we obtained regarding general beliefs for Language instruction could contribute to interpreting the lack of correlations between instructional practices and beliefs. To provide a context for future innovations, we collected data about teachers' self-efficacy beliefs on more general, less domainspecific dimensions, which are relevant for the quality of writing education (Lipson et al., 2000; Wang \& Matsumara, 2018). These dimensions included the subject, the pedagogical, and the social-educational dimension, which refer to "what" and "how" teachers communicate with their students, and the social dynamics in the classroom (Schiefele \& Shaffner, 2015).

On the one hand, the subject dimension scored highest on adherence. Specifically, self-efficacy beliefs about linguistic knowledge scored highest, while the knowledge about language-as-a-system was by far the highest of all general beliefs. This is consistent with the strong adherence to the traditional paradigms of writing instruction revealed by our findings (RQ1) and by earlier studies (Flórez Petour, 2011; Meneses, 2008; MINEDUC, 2009b). On the other hand, adherence to 
pedagogical self-efficacy beliefs revealed to be the lowest. Results for the pedagogical dimension revealed that teachers' self-efficacy beliefs regarding writing instruction in general $(50 \%)$ and for collaborative writing in particular $(33 \%)$ could be reinforced, as many teachers did not report feeling confident about teaching them (Figure 4).

Based on the above, we could infer that there is a gap between what teachers know regarding their subject, and how to implement instructional practices, which has been suggested by previous studies regarding reading instruction (Florez Petour, 2011). This might be one possible explanation for the lack of correlations between instructional practices and teachers' beliefs (RQ2). Nevertheless, more information from practice would be needed to clarify this issue. Therefore, conducting complementary qualitative studies seems to be needed to clarify this point regarding the measurement of instructional practices.

\subsubsection{Differences between educational levels}

We found differences in teachers' reports related to the two educational levels: Grades 7-8 and 9-12. Although their curricular requirements are similar, our findings suggest that each system requires a different emphasis. For instance, the paradigmatic coherence varied across subsystems of schooling. The macrolinguistic and the communicative paradigm appeared to be more coherent in Grades 7-8, while the micro-linguistic and the procedural paradigm appeared to be more coherent in Grades 9-12.

Such differences could be explained, in part, due to the variations in teachers' profiles between educational levels. Some signs that we obtained from this study and our previous study (Flores-Ferrés et al., 2020) indicate that teachers working in Grades 7-8 would be pedagogically trained, while their colleagues in Grades 9-10 receive preparation that is more content-focused. Regarding general beliefs, teachers working in Grades 7-8 reported feeling more confident about their socioeducational skills (such as classroom management and students' motivation), which were more clearly related to paradigms of writing instruction than in Grades 9-12. By contrast, teachers in Grades 9-12 felt more confident about their contentknowledge.

This would allow teachers in Grades 7-8 to implement more recommended writing practices. On one hand, the latter would explain why in Grades 9-12 the most coherent paradigm is the micro-linguistic, while in Grades 7-8 the most coherent paradigms are the macro-linguistic and cultural paradigms, which represent a greater challenge for pedagogical practices. On the other hand, this variation between the teaching profiles would not justify that the procedural paradigm is more coherent in Grades 9-12 since the procedural paradigm - in its strict interpretation- also requires advanced writing practices. However, it is possible that teachers in Chile implement procedural practices in a mechanical and linear way (Espinosa, 2018), as was also found in other countries (Lipson et al., 2000; 
Wang \& Matsumara, 2018). This would be less complex than teaching writing as a recursive process, as requested by the curricular requirements (MINEDUC, 2013). This point would require further studies that would allow us to delve into the way in which teachers understand and implement procedural practices in the classroom.

Such differences in professional culture imply that, if public policy makers aim to improve writing instruction in Chile, innovation strategies might be adapted to the variations between educational levels. Furthermore, our results appear to emphasize the need to prioritize improvements in secondary education (Grades 912). It seems that teachers working in upper grades are more content-focused and less prepared to manage the socio-educational dimension of their practices (see also Ryan et al., 2015).

\subsection{Conclusions}

Our first conclusion is that teachers implement a variety of domain-specific paradigms, which appear to be rather coherent among beliefs and practices. The communicative paradigm showed to be the only exception, for which teachers reported the lowest level of adherence (see Figure 3) and coherence (see Table 4). In secondary education (Grades 9-12) the communicative paradigm showed no internal coherence at all, as we did not find any correlations between teachers' beliefs and practices. It seems reasonable to assume that such results are not biased by sample representations: we would expect older teachers, those with lower academic degrees, and those working in Technical-Professional schools to adhere even less to the communicative paradigm, which represents a challenge for teachers, not only in Chile (Rietdijk et al., 2018).

Our second conclusion points to the patterns of correlations that we found between the constructs we measured (two types of beliefs and two types of practices), across all paradigms. Teachers' orientations generally correlate with teachers' self-efficacy beliefs, and both correlate with feedback practices. Nevertheless, teachers' beliefs did not correlate with instructional practices in any paradigm, which raises questions regarding how to interpret this finding. It seems plausible that teachers' understanding of recommended practices are better reflected by their beliefs and feedback practices, than by instructional practices in the classroom. However, more information is needed to delve into this issue.

Our third and fourth conclusions are based on the results that we obtained on more generic aspects related to writing and Language instruction. Our third conclusion is that our results suggest that there is room for improvement regarding teachers' confidence to teach writing, and especially to teach collaborative writing, compared to other aspects of Language instruction. Consistently, our previous study (Flores-Ferrés et al., 2020) indicated that most Chilean teachers working in Grades 7-12 reported being unsatisfied with their preparation for writing 
instruction, which seems to be mirrored in other countries (Veiga Simão et al., 2016; Gillespie et al., 2014).

Our fourth conclusion is that the more confident teachers feel about general aspects of Language instruction, the more they seem to adhere to specific beliefs about writing instruction, which in turn is likely to positively influence their writing practices as well. This is in line with previous international studies pointing out that, generic aspects of Language and/or teaching in general indeed appear to influence writing instruction in the classroom (Graham et al., 2002; Wang \& Matsumara, 2018; Lispon et al., 2000).

Our fifth conclusion is that the situation in Grades 7-8 and Grades 9-12 differs. Our data would suggest the presence of more quality processes of writing instruction in Grades 7-8 than in Grades 9-12. Teachers in Grades 7-8 seem to feel more confident than their colleagues from upper grades about socio-educational aspects related to their work in the classroom, which is likely to have positive effects on domain-specific aspects of writing instruction in Grades 7-8, compared to Grades 9-12. Those differences might be related to information collected by previous studies, which indicate a more favorable situation for writing instruction in lower grades than in higher grades. The results that we obtained in the previous study (Flores-Ferrés et al., 2020) indicate that, in comparison to teachers from Grades 9-12, those working in Grades 7-8 implement more recommended practices in their classrooms, that their preparation appears to be more positively related to their practices, and that their working conditions seem more positive for quality writing instruction. These findings are in line with the results from previous studies conducted in primary education (Bañales et al., 2020). Chilean teachers working in Grades 4-6 appear to implement a variety of evidence-based practices in the classroom, probably following the curricular requirements for literacy and writing instruction (MINEDUC, 2012). It seems that, compared to teachers from other countries, Chilean primary teachers implement a more intense writing program and are more positive about the preparation they received for writing instruction (Bañales et al., 2020). However, this favorable situation for writing instruction does not seem to be maintained in Grades 9-12. Our findings suggest that the preparation for teachers working in upper grades is more focused on content-knowledge, than on skills development.

We expect that the conclusions we drew from this study will be valuable at least in two regards. First, we expect that they will contribute as a basis of evidence for designing and improving effective educational public policies aiming to foster writing instruction in Chile. We think that gathering information from schools of all regions of the country has enabled us to provide rich input for policy makers. This is especially the case when intending to strengthen public schools, which, in Chile, form the most fragile educational sub-system. Second, we expect that our conclusions will enrich the international body of knowledge regarding quality 
writing instruction across the world. This study does so especially by providing insights to understand teaching processes of writing instruction from a broad and situated perspective. This means relating teachers' practices to teachers' beliefs, not only about writing instruction, but also about more general aspects of teaching and learning processes.

\subsection{Recommendations}

The gathered information allows us to draw four recommendations for future public policies in Chile, which could apply to other countries as well. International reports and Chilean national documents appear to assign great importance to ensuring that future generations learn to communicate effectively through writing (Flotts et al., 2016; MINEDUC, 2013). However, the limited adherence to the communicative paradigm that we found raises a worrying indicator in Chile - as well as in other countries (see Rietdijk et al., 2018). In addition, the lack of relations between teachers' beliefs and instructional practices by domain-specific paradigm points to a second issue of concern. Teachers' beliefs are key when aiming for educational innovation, since we assume they guide teachers' practices. Nevertheless, their lack of relations indicates an obstacle for educational change.

First, international studies confirm that specific intervention programs can promote communicative writing, integrated with other conceptualizations of writing instruction such as the procedural paradigm and strategy instruction (Rietdijk et al., 2017; Bouwer et al., 2018; De Smedt \& Van Keer, 2018). We recommend that, to implement such effective programs on a national level, they should be combined with other public efforts as well. This may require a social reconstructionist curricular orientation in which societal problems are key (McNeil, 1998), in combination with a humanistic (the cultural paradigm) and an academic orientation (linguistic and procedural paradigm).

Second, innovations need to ensure that teachers' beliefs are aligned with the desired curriculum change (Clark \& Peterson, 1986, Kyriakides et al., 2009; Rietdijk et al., 2018) - in this case, promoting communicative writing. We recommend revising the preparation that Language teachers are receiving in relation to literacy and writing instruction and implementing appropriate changes to adapt their training to the needs of the current educational system. This implies adjusting both pre-service and in-service teacher training, to ensure that both new teachers and those already in service can adjust to such changes (Jesson \& Parr, 2019).

Third, public efforts should ensure that the desired innovations actually reach the classroom level. This may imply first diagnosing the situation: why is it that instructional practices do not relate to teachers' beliefs by domain-specific level? Special attention should be placed on the relation between teachers' practices and teachers' beliefs, and factors that could influence this relation, such as contextual 
features of the teaching practice and programs of teacher professional development.

Fourth, policy makers need to put special effort into ensuring that teachers in Grades 9-12 receive the preparation they need to respond to curricular modernizations, and to the students they have in their classrooms. It seems that the situation of Chilean teachers working in primary education - up to Grade 8 -, is more favorable for providing students quality writing instruction than the situation of those working in Grades 9-12. This seems to be consistent with information obtained from other countries as well: in the U.S., the scenario in which middle school teachers work appears to be more complex than that in primary education (Ryan et al., 2015).

As a result, it is essential to adapt teacher training programs to the profiles of today's students and teachers (Bustos Balladares, 2019; Jesson \& Parr, 2019). This would require promoting a deep transformation of how the general teachinglearning processes are conceived, which may require a deconstruction of rooted educational structures - including teachers' and students' roles. Educational settings are in constant change (Jesson \& Parr, 2019), and have become increasingly complex (UNESCO, 2015), especially in middle and secondary schools (FloresFerrés et al., 2020; Ryan et al., 2015). In Chilean urban settings, this seems to be particularly the case, given the dominant role that secondary students from public schools have in the social processes that the country is experiencing (Cummings, 2017; Santiago et al, 2017; "Middle school students", 2019). Thus, if we aim to extend the (plausible) positive effects of the favorable conditions in Grades 7-8, public efforts should prioritize supporting teachers who work in Grades 9-12 to face the challenges they encounter in their classrooms.

Our recommendation for research is that follow-up studies are needed to improve the accuracy of the picture we aim to build about what writing instruction looks like in Grades 7-12 of Chilean public schools. First, it appears that the occurrence of communicative writing instruction is rare and that there is a need to delve into how procedural practices are implemented in the classroom. Second, writing instruction happens in practice, and instructional practices did not show to be related with teachers' beliefs. We recommend focusing on what kind of instructional sequences are implemented in different classroom, by teachers who differ in their belief system. This would help to identify the reasons of why beliefs change is not having an effect on instructional practices. Third, the very delicate situation in Grades 9-12 raises the urgent need to define the changes that need to be implemented to support teachers working at this educational level. Therefore, we would recommend complementary qualitative studies in Grade 9-12 that involve teacher interviews and/or classroom observations could help enrich the interpretation of the current study, and to show the potential positive basis regarding current teachers' practices and beliefs. 
397 | JOURNAL OF WRITING RESEARCH

\section{Notes}

1. We did not examine instructional practices (IP) regarding the microlinguistic paradigm. We prioritized to study the implementation of curricular modernizations and asking about micro-linguistic IP would have made the questionnaire overly long.

2. We wanted to estimate the median correlation between items by construct. Since the number of items included by construct was varied, we had to select one number to base the Spearman-Brown Prophecy formula on. We decided to base the formula on the number of items included within the construct with the highest number of them: the procedural instructional practices, which included seven items. We did so since this number included the other possibilities of the item's quantity within one construct (six, five, four and three).

3. Other communicative practices we asked about also revealed low implementation: asking students to write in the context of authentic projects and providing feedback to students regarding the readers' perspective: respectively, $15 \%$ and $10 \%$ implementation (for more information, see Flores-Ferrés et al., 2020).

\section{Acronyms}

BCNC Biblioteca del Congreso Nacional de Chile [Library of the National Congress of Chile]

MINEDUC Ministerio de Educación de Chile [Ministry of Education of Chile]

SIMCE Sistema de Medición de la Calidad de la Educación [System of Measurement of Education Quality]

\section{Acknowledgements}

We would like to acknowledge the support of the National Agency of Research and Development (in Spanish, ANID) of the Ministry of Science and Technology of Chile, for their financial support to this project. Their support was materialized through the BECAS CHILE grant obtained by Dra. Magdalena Flores-Ferrés in the 2015 call for proposals.

We would like to acknowledge the input provided by Steve Graham (US), and Carmen Sotomayor, Soledad Aravena, Isabel Sanhueza, Maili Ow, Lucía Oyarzún, Juana Marinkovich and Giovanni Parodi (Chile), during the development of the study's questionnaire and by Carlos Alcalde and Paloma Opazo during the validation of the translation into Spanish. Furthermore, we are grateful for the books provided by Fundación Mustakis (Chile) as a reward for survey participants and for the contribution Huub van den Bergh (The Netherlands) made to the data analysis. 


\section{References}

Agencia Nacional de la Educación (n.d). SIMCE. Retrieved from https://www.agenciaeducacion.cl/evaluaciones/que-es-el-simce/

Arellano, J.P. (2001). La reforma educacional chilena [The Chilean educational reform]. Revista CEPAL (Economic Comission for Latin America and Caribe), 73, 83-94. http://www.institutgouvernance.org/es/document/fiche-document-150.html

Assaf, L. C., Ralfe, L., \& Steinbach, B. (2016). South African teachers learning to become writers and writing teachers: A study of generative learning. Teaching and Teacher Education, 56, 173-184. https://doi.org/10.1016/j.tate.2016.02.011

Ávalos, B. (2010). Teacher identity construction in reform driven contexts (2010). Journal of A// India Association for Educational Research, 22(2).www.ejournal. aiaer.net

Ávalos, Beatrice. (2016). Developing professionalism in uncertain educational environments: A trajectory study of new teachers in Chile, presented at the American Educational Research Association (AERA) Annual Meeting, Washington D.C., April 2016. https://www.researchgate.net/publication/301328557_Developing_professionalism_in_un certain_educational_environments_A_trajectory_study_of_new_teachers_in_Chile

Bandura, A. (1977). Self-efficacy: Toward a unifying theory of behavioral change. Psychological Review, 84(2), 191-215. https://doi.org/10.1037/0033-295X.84.2.191

Bandura, A. (1986). Social foundations of thought and action: A social cognitive theory. New Jersey: Prentice-Hall.

Bañales, G., Ahumada, S., Graham, S., Puente, A., Guajardo, M., \& Muñoz, I. (2020). Teaching writing in grades 4-6 in urban schools in Chile: a national survey. Reading and Writing. https://doi.org/10.1007/s11145-020-10055-z

Bañales, G., Ahumada, S., Martínez, R., Martínez, M., \& Messina, P. (2018). Investigaciones de la escritura en la educación básica en Chile: revisión de una década (2007-2016) [Research of writing in primary education in Chile: A review of a decade (2007-2016)]. RLA. Revista de Lingüística Teórica y Aplicada, 56(1), 59-84. https://doi.org/10.4067/s0718-48832018000100059

Barton, D.,; Ivanic, R., \&; Hamilton, M. (2000). Situated literacies: Theorising reading and writing in context. London: Routledge.

Bellei, C., Contreras, M., Canales, M., \& Orellana, V. (2019). The production of socio-economic segregation in chilean education: school choice, social class and market dynamics. In X. Bonal, \& C. Bellei (Eds.) Understanding school segregation. Patterns, causes, and consequences of spatial inequalities in education (p.221-240). London: Bloomsbury.

Bereiter, C., \& Scardamalia, M. (2009). The psychology of written composition. New York: Routledge.

Bouwer, R.,; Koster, M., \&; van den Bergh, H. (2018). Effects of a strategy-focused instructional program on the writing quality of upper elementary students in the Netherlands. Journal of Educational Psychology, 110(1):58-71. https://doi.org/10.1037/edu0000206

Brindle, M. (2013). Examining relationships among teachers' preparation, efficacy, and writing practices. Nashville: Vanderbilt University.

Bustos Balladares, A. (2019). Desarrollo emocional del profesor: una dimensión que urge cultivar en la sociedad actual [Teachers' emotional development: a dimension that is urges to cultivate in nowadays' society]. In Torres Durán, B. (Ed.), Educación, escuela y profesorado: Aportes desde el consejo de decanos de facultades de educación del consejo de rectores de las universidades chilenas. [Education, school and teachers: Contributions from the Deans of Faculties of Education of the Council of Rectors of Chilean Universities] (pp. 13-27). Concepción: Universidad de Concepción.

Cabezas, V., Paredes, R., Bogolasky, F., Rivero, R., \& Zarhi, M. (2017). First job and the unequal distribution of primary school teachers: Evidence for the case of Chile. Teaching and Teacher Education, 64, 66-78. https://doi.org/10.1016/j.tate.2017.01.017 
399 | JOURNAL OF WRITING RESEARCH

Centro de Estudios MINEDUC.(2017). Directorio oficial de docentes 2017 [Official directory of teachers 2017]. http://datosabiertos.mineduc.cl/

Clark, C. \& Peterson, P. (1986). Teachers' thought processes. In M. Wittrock (Ed.) Handbook of Research on Teaching (3rd ed., p. 255-296). New York: Mac Millan.

Cornejo Chávez, R. (2009). Condiciones de trabajo y bienestar/malestar docente en profesores de enseñanza media de Santiago de Chile [Secondary teachers working conditions and wellbeing / illbeing in Santiago de Chile]. Educação \& Sociedade, 30(107), 409-426. https://doi.org/10.1590/s0101-73302009000200006

Correa, R., Tapia, M., Neira, A. \& Ortiz, M. (2013). Teorías personales de docentes de lengua sobre la enseñanza de la escritura en el sistema de educación pública chilena. [Language teacher personal theories about teaching writing in the chilean public educational system] Trab. Ling. Aplic., Campinas, 52(1), 165-184. https://doi.org//10.1590/S010318132013000100010.

Cox, C. (2001a). Políticas de reforma curricular en Chile [Curricular reform policies in Chile]. Pensamiento Educativo, 29, 177-193. http://pensamientoeducativo.uc.cl/

Cox, C. (2001b). El curriculum escolar del futuro [The scholar curriculum of the future] Revista Perspectivas, 4(2), 213-232.from http://www.dii.uchile.cl/ revista/

Cummings, P. (2017, February 21). Student movement in Chile: Explaining a protest paradox. Panoramas.https://www.panoramas.pitt.edu/health-and-society/student-movement-chileexplaining-protest-paradox

Cutler, L., \& Graham, S. (2008). Primary grade writing instruction: A national survey. Journal of Educational Psychology, 100(4), 907-919. https://doi.org/10.1037/a0012656

De Smedt, F. \& Van Keer, H. (2018).Fostering writing in upper primary grades: a study into the distinct and combined impact of explicit instruction and peer assistance. Reading and Writing, 31(2), 325-354. https://doi.org/10.1007/s11145-017-9787-4

De Smedt, F., Van Keer, H., \& Merchie, E. (2016). Student, teacher and class-level correlates of Flemish late elementary school children's writing performance. Reading and Writing, 29(5), 833-868. https://doi.org/10.1007/s11145-015-9590-z

Dillman, D; Smyth, J., \& Christian, L.M. (2014). Internet, phone, mail, and mixed-mode surveys: The tailored design method (4th ed.). New Jersey: John Wiley and Sons.

Dix, S. (2012). Discursively complex identities of New Zealand teachers of writing in times of contestation and change. Teaching and Teacher Education, 28(3), 405-417. https://doi.org/10.1016/j.tate.2011.11.004

Espinosa, M.J. (2018). Enseñanza de la escritura en la escuela: Qué, cómo y por qué enseñan así los docentes [Writing instruction in the school: Understanding the what, how and why of teachers practices] (Doctoral dissertation) Universidad Alberto Hurtado, Santiago, Chile. http://repositorio.uahurtado.cl/handle/11242/24204.

Espinoza, O., González, L. E., McGinn, N., Sandoval, L., \& Castillo, D. (2020). Should universities train teachers for employability or for effectiveness? Teaching and Teacher Education, 88 , 102960. https://doi.org/10.1016/j.tate.2019.102960

Field, A. (2013). Discovering statistics using IBM SPSS statistics (4th ed.). Brighton: University of Sussex.

Flores-Ferrés, M.; van Weijen, D., \& Rijlaarsdam, G. (2020). Teachers' writing practices and contextual features in grades 7-12 of chilean public schools. Journal of Writing Research, 12(2), 365-417. https://doi.org/https://doi.org/10.17239/jowr-2020.12.02.03

Flórez Petour, T. (2011). Lengua castellana y comunicación en el aula de educación secundaria [Spanish Language and Communication in secondary classrooms]. Revista Latinoamericana de Estudios Educativos, 41(1-2), 61-102. https://www.redalyc.org/pdf/270/27021144003.pdf

Flotts, P.,; Manzi, J,; Lobato, P.,; Durán, M.I.,; Díaz, M.P. \&; Abarzúa, A. (2016). Aportes para la enseñanza de la escritura [Contributions for writing instruction]. Santiago: UNESCO Santiago. 
Flower, L., \& Hayes, J. R. (1981). A cognitive process theory of writing. College Composition and Communication, 32(4), 365-387 365. https://doi.org/10.2307/356600

Fonseca-Chacana, J. (2019). Making teacher dispositions explicit: A participatory approach. Teaching and Teacher Education, 77, 266-276. https://doi.org/10.1016/j.tate.2018.10.018

Gillespie, A., Graham, S., Kiuhara, S., \& Hebert, M. (2014). High school teachers use of writing to support students' learning: a national survey. Reading and Writing, 27(1043-1072). https://doi.org/10.1007/s11145-013-9494-8

Gómez, G., Sotomayor, C., Jéldrez, E., Bedwell, P. \& Domínguez, A. M. (2016). La producción escrita de estudiantes y escuelas en base a resultados Simce, factores contextuales y modelos de buenas prácticas docentes. [Written production of students and schools based on SIMCE results, contextual factors and models of good teaching practices]. Chile: Centro de Estudios Ministerio de Educación. https://centroestudios.mineduc.cl/wp-content/uploads/sites/100/2017/07/INFORME-FINAL-F911437.pdf

Grabowski, J.; Mathiebe, M.; Hachmeister, S., \& Becker-Mrotzek, M. (2018). Teaching perspective taking and coherence generation to improve cross-genre writing skills in secondary grades: A detailed explanation of an intervention. Journal of Writing Research, 10(2), 331-356. https://doi.org/10.17239/jowr-2018.10.02.06

Graham, S. (2019). Changing how writing is taught. Review of Research in Education, 43(1), 277303. https://doi.org/10.3102/0091732x18821125

Graham, S., \& Rijlaarsdam, G. (2016). Writing education around the globe: Introduction and call for a new global analysis. Reading and Writing, 29(5), 781-792. https://doi.org/10.1007/s11145-016-96401

Graham, S., Capizzi, A., Harris, K. R., Hebert, M., \& Morphy, P. (2013). Teaching writing to middle school students: a national survey. Reading and Writing, 27(6), 1015-1042. https://doi.org/10.1007/s11145-013-9495-7

Graham, S., Harris, K. R., MacArthur, C. A., \& Fink, B. (2002). Primary grade teachers' theoretical orientations concerning writing instruction: Construct validation and a nationwide survey. Contemporary Educational Psychology, 27, 147-166. https://doi.org/10.1006/ceps.2001.1085

Graham, S., Hebert, M., \& Harris, K. R. (2015). Formative assessment and writing. The Elementary School Journal, 115(4), 523-547. https://doi.org/10.1086/681947

Guba, E. (1990). The paradigm dialog. London: SAGE publications.

Gysling, J. (2016). The historical development of educational assessment in Chile: 1810-2014. Assessment in Education: Principles, Policy \& Practice, 23(1), 8-25. https://doi.org/10.1080/0969594x.2015.1046812

Hayes, J. R. (1996). A new framework for understanding cognition and affect in writing. In Levi, C. M. \& Ransdell, S. (Eds.) The science of writing: theories, methods, individual differences and applications (pp. 6-44). New Jersey: Lawrence Erlbaum.

Holzberger, D., Philipp, A. \& Kunter, M. (2014). Predicting teachers' instructional behaviors: The interplay between self-efficacy and intrinsic needs. Contemporary Educational Psychology, 39, 100-111. https://doi.org/10.1016/j.cedpsych.2014.02.001

Hymes, D.H. (1972). On communicative competence. In J.B. Pride, \& J. Holmes (Eds.), Sociolinguistics. Selected Readings (part 2, p. 262-293). Harmondsworth: Penguin.

Jesson, R., \& Parr, J. (2019). Writing interventions that respond to context: Common features of two research practice partnership approaches in New Zealand. Teaching and Teacher Education, 86, 102902. https://doi.org/10.1016/j.tate.2019.102902

Kiuhara, S. A., Graham, S., \& Hawken, L. S. (2009). Teaching writing to high school students: A national survey. Journal of Educational Psychology, 101(1), 136-160. https://doi.org/10.1037/a0013097

Klein, P. D., \& Boscolo, P. (2016). Trends in research on writing as a learning activity. Journal of Writing Research, 73), 311-350.https://doi.org/10.17239/jowr-2016.07.03.01

Kuhn, T. (1962). The structure of scientific revolutions. Chicago: University of Chicago. 
401 | JOURNAL OF WRITING RESEARCH

Kyriakides, L., Creemers, B. P. M., \& Antoniou, P. (2009). Teacher behaviour and student outcomes: Suggestions for research on teacher training and professional development. Teaching and Teacher Education, 25(1), 12-23. https://doi.org/10.1016/j.tate.2008.06.001

Leicht, A., Heiss, J., \& Byun, W. (2018). Issues and trends in education for sustainable development, education on the move, UNESCO Publishing: Paris. http://unesdoc.unesco.org/images/0026/002614/261445e.pdf>.

Lipson, M. , Mosenthal, J. Daniels, P. \& Woodside- Jiron, H. (2000). Process writing in the classrooms of eleven fifth-grade teachers with different orientations to teaching and learning. The Elementary School Journal, 101,(2),. 209-231. https://doi.org/10.1086/499665

McCartey, S., \& Mkhize, D.(2013). Teachers' orientations towards writing. Journal of Writing Research, 5(1), 1-33. https://doi.org/10.17239/jowr-2013.05.01.1

McNeil, J.D. (1998). Curriculum: A comprehensive introduction. (5th ed.). New York: HarperCollins.

Meneses, A. (2008). Leer y escribir en una escuela chilena: Representaciones discursivas de los diferentes agentes educativos en las áreas prioritarias delcurrículo escolar en NB3. Revista Signos, 41(67), 257-278. . https://doi.org/10.4067/s0718-09342008000200010

Messer, B. L., \& Dillman, D. A. (2011). Surveying the general public over the internet using address-based sampling and mail contact procedures. Public Opinion Quarterly, 75(3), 429-457. https://doi.org/10.1093/poq/nfr021

Middle school students started a movement that has paralyzed Chile's capital. (2019, October 19). Los Angeles Times. https://www.latimes.com/world-nation/story/2019-10-19/protestsparalyze-chile-capital

MINEDUC. (2009a). Objetivos fundamentales y contenidos mínimos obligatorios de la Educación Básica y Media. Actualización 2009 [Fundamental objectives and minimum obligatory contents for primary and secondary education. 2009 Update] http://www.agenciaeducacion.cl/wp-content/uploads/2013/02/Marco-Curricular-yActualizacion-2009-I-a-IV-Medio.pdf

MINEDUC. (2009b). Fundamentos del ajuste curricular en el sector de Lenguaje y Comunicación [Foundations of the curricular adjustment of Language and Communication] http://ww2.educarchile.cl/UserFiles/P0001/File/ajuste_curricular/ Fundamentos_Lenguaje.pdf

MINEDUC. (2012). Bases curriculares de la educación básica [Curricular framework for primary education]. https://www.curriculumnacional.cl/614/articles-22394_bases.pdf

MINEDUC. (2013). Bases curriculares de Séptimo básico a Segundo medio: Lengua y LLiteratura [Curricular framework for grades from 7th to 10th: Language and Literature]. http://www.curriculumenlineamineduc.cl/605/articles-30013_recurso_17_08.pdf

MINEDUC. (2019). Texto definitivo. Bases curriculares $3^{\circ}$ y $4^{\circ}$ medio [Final text: Curricular framework for Grades 11-12]. Author. https://www.curriculumnacional.cl/ portal/Secciones/3-y-4-medio/89597:3-y-4-ano-medio-Nuevo-Curriculum

Moffett, J. (1983). Teaching the universe of discourse. Portsmouth: Heinemann.

Nicholls, S. (2009). Beyond expressive writing. Journal of Health Psychology, 14(2), 171 180.https://doi.org/10.1177/1359105308100201

OECD. (2018). Effective teacher policies: Insights from PISA. PISA, OECD Publishing. http://dx.doi.org/10.1787/9789264301603-en

OECD. (2019). Students' socio-economic status and performance. In Author (Ed.). PISA 2018 Results (Volume II): Where Al/ Students Can Succeed. https://doi.org/10.1787/b5fd1b8f-en

Pajares, F. (1992). Teachers' beliefs and educational research: Cleaning up a messy construct. Review of Educational Research, 62(3), 307 -332. doi.org/10.3102/00346543062003307

Parr, J. M., \& Limbrick, L. (2010). Contextualising practice: Hallmarks of effective teachers of writing. Teaching and Teacher Education, 26(3), 583-590.

https://doi.org/10.1016/j.tate.2009.09.004 
Prior, P. (2006). A sociocultural theory of writing. In MacArthur, C.; Graham, S. \& Fitzgerald, J. (Eds.), Handbook of writing research (p. 54-66). New York: The Guilford Press.

Programa de educación intercultural bilingue MINEDUC. (2017). Programa de educacióon intercultural bilingue 2010 - 2016 [Program of Intercultural Bilingual Education 2010-2016]. Santiago: Author.

Ramaprasad, A. (1983). On the definition of feedback. Behavioral Science, 28, 4-13. doi.org/10.1002/bs.3830280103

Rietdijk, S., Janssen, T., van Weijen, D., Van den Bergh, H., \& Rijlaarsdam, G. (2017). Improving writing in primary schools through a comprehensive writing program. Journal of Writing Research, 9(2), 173-225. https://doi.org/10.17239/jowr-2017.09.02.04

Rietdijk, S., van Weijen, D., Janssen, T., Van den Bergh, H., \& Rijlaarsdam, G. (2018). Teaching writing in primary education: Classroom practice, time, teachers' beliefs and skills. Journal of Educational Psychology, 110(5), 640-663. https://doi.org/10.1037/edu0000237

Rijlaarsdam, G., \& Braaksma, M. (2015). Introduction to the special issue on writing-to-learn studies. Journal of Writing Research, 7(1), 1-4. https://doi.org/10.17239/jowr-2015.07.01.01

Rijlaarsdam, G., Braaksma, M., Couzijn, M., Janssen, T., \& Raedts, M. Toorenaar, A. \& Van den Bergh, H. (2008). Observation of peers in learning to write. Practise and research. Journal of Writing Research, 1(1), 53-83. https://doi.org/10.17239/jowr-2008.01.01.3

Rijlaarsdam, G., Braaksma, M., Couzijn, M., Janssen, T., Kieft, M., Raedts, M., Van Steendam, E., Toorenaar, A., Van den Bergh, H. (2009). The role of readers in writing development: Writing students bringing their texts to the test. In R. Beard, D. Myhill, J. Riley \& M. Nystrand (Eds.). The SAGE handbook of writing development (p. 436-452). London: SAGE publications.

Rosenfeld, B., Imai, K., \& Shapiro, J. N. (2015). An empirical validation study of popular survey methodologies for sensitive questions. American Journal of Political Science, 60(3), 783 802. https://doi.org/10.1111/ajps.12205

Ryan, A., Kuusinen, C. \& Bedoya-Skoog, A. (2015). Managing peer relations: A dimension of teacher self-efficacy that varies between elementary and middle school teachers and is associated with observed classroom quality. Contemporary Educational Psychology, 41, 147-156. https://doi.org/10.1016/j.cedpsych.2015.01.002

Sadler, D. R. (1989). Formative assessment and the design of instructional systems. Instructional Science, 18(2), 119-144. https://doi.org/10.1007/bf00117714

Santiago, P., Benavides, F., Danielson, C., Goe, L., Nusche, D. (2013). Teacher evaluation in Chile 2013. https://doi.org/10.1787/9789264172616-en

Santiago, P., Fiszbein, A., García-Jaramillo, S. \& Radinger, T. (2017). OECD Reviews of school resources: Chile 2017. In OECD Reviews of School Resources, OECD Publishing. doi.org/10.1787/9789264285637-en

Sawyer, W., \& Van de Ven, P. (2006). Starting points. Paradigms in mother-tongue education. L1- Educational Studies in Language and Literature, 71), p. 5-20. https://doi.org/10.17239/11esIl-2007.07.01.06

Schiefele, U., \& Schaffner, E. (2015). Teachers interest, mastery goals, and self-efficacy as predictors of instructional practices and student motivation. Contemporary Educational Psychology, 42, 159-171. https://doi.org/10.1016/j.cedpsych.2015.06.005

Shulman, L. (1987). Knowledge and teaching: Foundations of the new reform. Harvard Educational Review, 571), 1-23. https://doi.org/10.17763/haer.57.1.j463w79r56455411

Silva Peña, I., Tapia, T., \& Ibáñez, M. (2016). Concepciones docentes sobre la escritura en primer año de Educación Básica. Paradigma, 371) 46 - 60.

http://ve.scielo.org/scielo.php?script=sci_arttext\&pid=S1011-22512016000100004

Sturk, E., \& Lindgren, E. (2019). Discourses in teachers' talk about writing. Written Communication, 36(4), 503-537. https://doi.org/10.1177/0741088319862512

Ten Brinke, S. (1976). The complete mother-tongue curriculum. Groningen, the Netherlands: Wolters- Noordhoff Longman. 
403 | JOURNAL OF WRITING RESEARCH

Troia, G., Lin, S., Cohen, S., \& Monroe, B. (2011). A year in the writing workshop: linking writing instruction practices and teachers' epistemologies and beliefs about writing instruction. The Elementary School Journal, 112(1), 155-182. https://doi.org/10.1086/660688

Tschannen-Moran, M., Hoy, A. W., \& Hoy, W. K. (1998). Teacher Efficacy: Its meaning and measure. Review of Educational Research, 68(2), 202-248. https://doi.org/10.3102/00346543068002202

UNESCO.(2012). International standard classification of education ISCED 2011. Montreal: UNESCO Institute for Statistics.

UNESCO.(2015). Rethinking education: Towards a global common good? Paris: Author.

UNESCO.(2016). Education 2030: Incheon declaration and framework for action for the implementation of sustainable development goal 4: Ensure inclusive and equitable quality education and promote lifelong learning opportunities for all. Paris, France: Author.

Veiga Simão, A. M., Abreu Malpique, A., Bagagnolo Frison, L., \& Marques, A. (2016). Teaching writing to middle school students in Portugal and in Brazil: an exploratory study. Reading and Writing, 29(5), 955-979. https://doi.org/10.1007/s11145-015-9606-8

Viennet, R., \& Pont, B. (2017). Education policy implementation: A literature review and proposed framework. (OECD working paper No. 162). https://doi.org/10.1787/fc467a64-en

Von Suchodoletz, A., Jamil, F., Larsen, R., \& Hamre, B. (2018). Personal and contextual factors associated with growth in preschool teachers' self-efficacy beliefs during a longitudinal professional development study. Teaching and Teacher Education, 75, 278-289. https://doi.org/10.1016/j.tate.2018.07.009

Wang, E.L., \& Mastumara, L.C. (2018). Text-based writing in elementary classrooms: teachers' conceptions and practice. Reading and Writing, 32(2), 405438.https://doi.org/10.1007/s11145-018-9860-7

Zee, M., \& Koomen, H. (2016). Teacher self-efficacy and its effects on classroom processes, student academic adjustment, and teacher well-being: a synthesis of 40 years of research. Review of Educational Research, 86(4) (981-1015). https://doi.org/10.3102/0034654315626801 


\section{Appendix A: Instrument structure}

Table A1 provides information on the types of questions included in the questionnaire:

- Multiple choice items, which included single answer items (A.1), multiple answer items (A.2), and classification items (A.3), which required respondents to group items by dragging them into boxes on the screen.

- $\quad$ Text entry items $(\mathrm{B})$

Items within the domain-specific level of writing instruction are related to the linguistic, communicative, procedural, and cultural paradigms. 
405 | JOURNAL OF WRITING RESEARCH

Table A1. Questionnaire Structure. Teachers' practices and beliefs

\begin{tabular}{|c|c|c|c|c|c|c|c|}
\hline $\begin{array}{l}\text { Survey } \\
\text { section }\end{array}$ & & Category & $\begin{array}{l}\text { Item } \\
\text { type }\end{array}$ & $\begin{array}{l}\mathrm{N} \text { of } \\
\text { varia } \\
\text { bles }\end{array}$ & Example questions & Options & $\begin{array}{l}\text { M number of choices } \\
\text { selected } 1\end{array}$ \\
\hline \multirow[t]{3}{*}{$\begin{array}{l}\text { Practices } \\
\text { and } \\
\text { beliefs }\end{array}$} & $\begin{array}{l}\text { Domain- } \\
\text { specific } \\
\text { level }\end{array}$ & $\begin{array}{l}\text { Instructional } \\
\text { practices }\end{array}$ & A. 1 & 8 & $\begin{array}{l}\text { My students plan the texts they write. } \\
\text { My students express their own } \\
\text { thoughts while writing }\end{array}$ & $\begin{array}{l}\text { Never, sometimes } \\
\text { during the year, } \\
\text { sometimes during the } \\
\text { semester, sometimes } \\
\text { during the month, } \\
\text { sometimes during the } \\
\text { week. }\end{array}$ & - \\
\hline & & & A. 3 & 8 & $\begin{array}{l}\text { My students send their texts to a real } \\
\text { addressee, such as a classmate or a } \\
\text { relative. } \\
\text { My students write texts based on } \\
\text { research they do themselves }\end{array}$ & $\begin{array}{l}\text { Very often, a few times, } \\
\text { never }\end{array}$ & $\begin{array}{l}\text { M3.4 practices ( } s d=1.5) \\
\text { regularly implemented. }\end{array}$ \\
\hline & & $\begin{array}{l}\text { Teachers' } \\
\text { orientations }\end{array}$ & A. 3 & 12 & $\begin{array}{l}\text { How relevant are the following aspects } \\
\text { for your writing lessons? } \\
\text { Personal expression, Identity } \\
\text { development, the readers' perspective, } \\
\text { among others. }\end{array}$ & $\begin{array}{l}\text { Great, low, no } \\
\text { relevance. }\end{array}$ & $M 9.7(s d=3)$ \\
\hline
\end{tabular}


Self - efficacy

beliefs

\section{General Self - efficacy \\ level}

A. $2 \quad 10$

se

objectives of a writing lesson. Please

select those for which you feel most

confident. You can select more than

$$
\text { one. }
$$

A. 212

From the following aspects relevant to your classroom work, select the ones that you best master. You can select more than one.

Context

\section{Personal}

characteristics

A.1

\section{3}

Please indicate your gender

School

A.1

A. 2

B

Class

8

Pleas

How many students are there in your class?
WRITING CURRICULUM INNOVATION IN CHILE | 406

Help my students to

$M 5,8(s d=2)$

improve their

formulation skills

(vocabulary, grammar

and/or spelling).

Help my students to

develop their ideas

while writing.

Classroom

$M 6,8(s d=2,6)$

management, linguistic

knowledge, writing

instruction, among

others.

Male, female, other

Note. Based on Flores-Ferrés et al. (2020, see Tables 7, 8 and 9). ${ }^{1}$ Only A.3 \& A.4 items. 


\section{Appendix B: Sample representation}

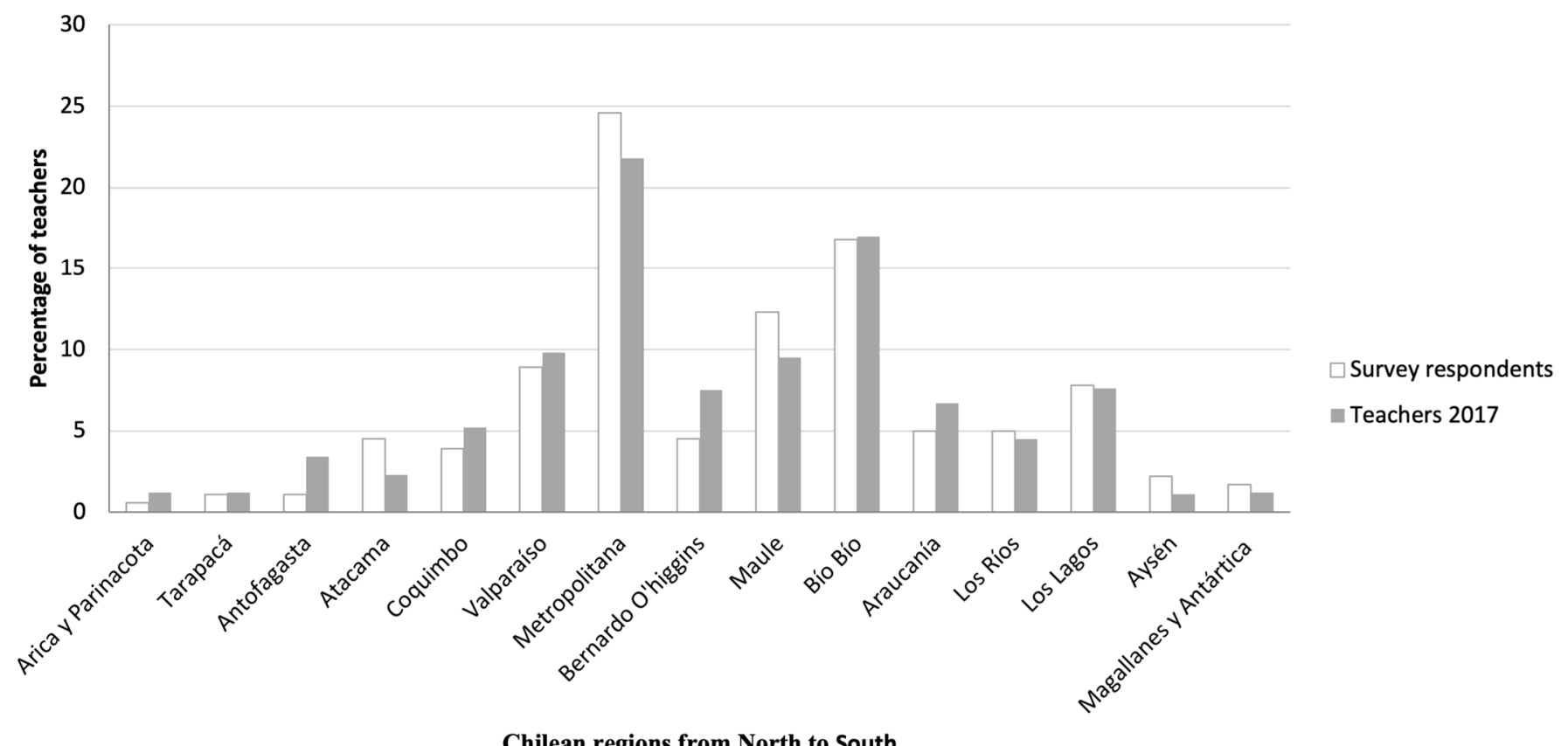

Figure B1. Comparison of geographical distribution between survey respondents and the actual population of Language teachers across Chile (Flores-Ferrés et al., 2020). Data of teachers' population was obtained from Centro de Estudios MINEDUC (2017). 
Table B1. Participants' Personal, School and Class Information

FLORES-FERRÉS · UNDERSTANDING WRITING CURRICULUM INNOVATION IN CHILE 408

\begin{tabular}{|c|c|c|c|c|c|c|c|}
\hline & Variable & Information & & $\begin{array}{l}\text { National data } \\
\%\end{array}$ & Source & $\begin{array}{l}\text { Survey } \\
\%\end{array}$ & $\begin{array}{l}\text { Mean } \\
(S D)\end{array}$ \\
\hline \multirow{3}{*}{$\begin{array}{l}\text { Personal } \\
\text { characteristics }\end{array}$} & Age & \multicolumn{2}{|l|}{$<40$ years old } & 51 & Santiago et al., 2013 & 58 & \\
\hline & Gender & \multicolumn{2}{|l|}{ Female } & 69 & $\begin{array}{l}\text { Centro de estudios } \\
\text { MINEDUC, } 2017\end{array}$ & 80 & \\
\hline & Years of experience & & & 15 & Santiago et al., 2013 & & $10(9)$ \\
\hline \multirow[t]{2}{*}{$\begin{array}{l}\text { Professional } \\
\text { development }\end{array}$} & \multirow{5}{*}{ Curriculum } & \multicolumn{2}{|c|}{ Participants with a teaching degree } & 94 & $\begin{array}{l}\text { Centro de Estudios } \\
\text { MINEDUC, } 2017\end{array}$ & 100 & \\
\hline & & \multicolumn{2}{|c|}{$\begin{array}{l}\text { Participants who continued their studies after their } \\
\text { teaching degree }\end{array}$} & 19 & & 31 & \\
\hline \multirow[t]{4}{*}{ School } & & Branches & Scientific-Humanistic & 58 & Santiago et al., 2013 & 70 & \\
\hline & & & $\begin{array}{l}\text { Technical- } \\
\text { Professional }\end{array}$ & 42 & Santiago et al., 2013 & 29 & \\
\hline & & \multicolumn{2}{|c|}{ Indigenous language instruction ${ }^{1}$} & 15 & $\begin{array}{l}\text { Programa de Educación } \\
\text { Intercultural Bilingüe } \\
\text { MINEDUC, } 2017\end{array}$ & 13 & \\
\hline & $\begin{array}{l}\text { With preferential } \\
\text { state support }(\mathrm{SEP})^{2}\end{array}$ & & & 99 & BCNC, 2018 & 93 & \\
\hline \multirow[t]{4}{*}{ Class } & \multirow[t]{3}{*}{$\begin{array}{l}\text { Number of students } \\
\text { per group }\end{array}$} & Grades 7-12 & & 32 & Santiago et al., 2013 & & $31(15)$ \\
\hline & & & Grades 7-8 & 29 & & & $26(15)$ \\
\hline & & & Grades 9-12 & $\begin{array}{l}\text { Sometimes, }>45 \text { in } \\
\text { urban schools }\end{array}$ & $\begin{array}{l}\text { Cornejo Chávez, 2009; } \\
\text { Ávalos, } 2010\end{array}$ & & $35(14)$ \\
\hline & $\begin{array}{l}\text { Weekly L1 teaching } \\
\text { hours }\end{array}$ & Grades 7-12 & & 6 & BCNC, 2014a & & $6.5(1.4)$ \\
\hline
\end{tabular}

Note. (1) From (Flores-Ferrés et al., 2020). Schools with more than 20\% of indigenous students implement the Indigenous Language curriculum. (2) SEP (In Spanish, Subvención escolar

preferencial) is a special form of state support that is provided to public schools with students from low socio-economic backgrounds 


\section{Appendix C: Teachers' practices and beliefs}

Table C1. Domain-specific Practices

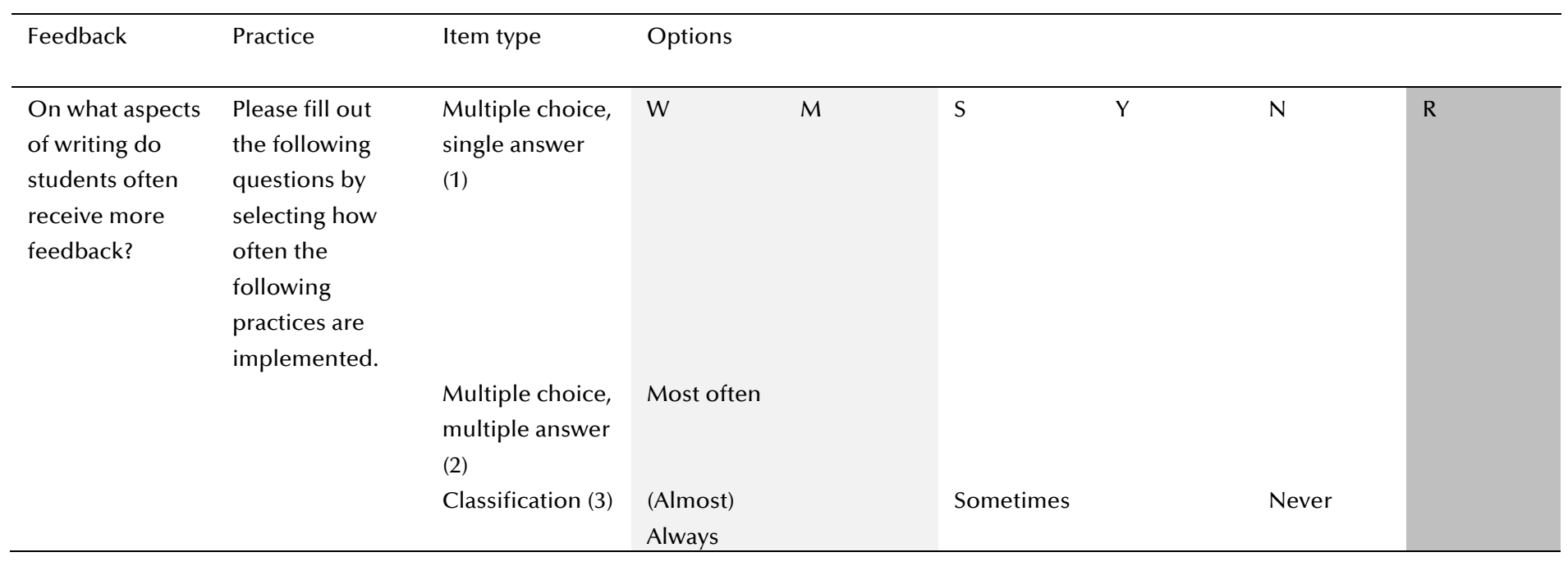

Note. $\mathrm{W}=$ Weekly, M=Monthly, S=By semester, $\mathrm{Y}=$ Yearly, $\mathrm{N}=$ Never, $\mathrm{R}=$ Regularly implemented 


\begin{tabular}{|c|c|c|c|c|c|c|c|c|c|}
\hline \multirow[t]{2}{*}{ Paradigm } & \multirow[t]{2}{*}{ Practice } & \multirow{2}{*}{$\begin{array}{l}\text { Item } \\
\text { type }\end{array}$} & \multirow[t]{2}{*}{$\mathrm{N}$} & \multicolumn{6}{|c|}{ Percentages } \\
\hline & & & & W & M & $\mathrm{S}$ & $\mathrm{Y}$ & $\mathrm{N}$ & $\mathrm{R}$ \\
\hline Linguistic & Spelling & 3 & 182 & 81 & & & & & 81 \\
\hline Micro & Grammar & 3 & 182 & 49 & & & & & 49 \\
\hline \multirow[t]{2}{*}{ Macro } & Textual organization & 3 & 182 & 66 & & & & & 66 \\
\hline & Students practice ways of structurally organizing the texts they write & 2 & 149 & 46 & & 32 & & 4 & 46 \\
\hline \multirow{3}{*}{$\begin{array}{l}\text { Communi- } \\
\text { cative }\end{array}$} & Readers' perspective & 3 & 182 & 10 & & & & & 10 \\
\hline & My students share their written texts with each other & 1 & 182 & 18 & 43 & 24 & 13 & 2 & 61 \\
\hline & $\begin{array}{l}\text { My students send their written products to a real recipient } \\
\text { (such as a relative or an authority). }\end{array}$ & 2 & 153 & 2 & & 40 & & 42 & 2 \\
\hline \multirow[t]{7}{*}{ Procedural } & Writing process & 3 & 182 & 52 & & & & & 52 \\
\hline & My students plan the texts they will write & 1 & 182 & 23 & 46 & 24 & 7 & 1 & 69 \\
\hline & My students review the texts they write & 1 & 182 & 31 & 43 & 20 & 5 & 0 & 74 \\
\hline & My students plan their texts together & 1 & 182 & 12 & 41 & 28 & 13 & 4 & 53 \\
\hline & My students use a computer to support their writing process & 1 & 182 & 17 & 34 & 34 & 15 & 4 & 51 \\
\hline & My students rewrite their texts to better suit their communicative purposes & 2 & 164 & 63 & & 32 & & 5 & 63 \\
\hline & My students receive feedback before submitting the final version of their texts & 1 & 168 & 71 & & 19 & & 2 & 71 \\
\hline \multirow[t]{4}{*}{ Cultural } & Creativity & 3 & 182 & 38 & & & & & 38 \\
\hline & Personal expression & 3 & 182 & 31 & & & & & 31 \\
\hline & Aesthetics of language & 3 & 182 & 7 & & & & & 7 \\
\hline & Development of ideas & 3 & 182 & 78 & & & & & 78 \\
\hline
\end{tabular}


411| JOURNAL OF WRITING RESEARCH

Table $C 2$. Teachers' beliefs about writing instruction: Theoretical Orientations. Percentage of participants that selected giving relevance to the aspect in their writing lessons $(\mathrm{N}=182)$

\begin{tabular}{lll}
\hline Paradigm & Item & Percentage \\
Linguistics & & \\
Micro & Spelling & 74 \\
& Vocabulary & 77 \\
Macro & Grammar & 65 \\
Communicative & Textual organization & 70 \\
Procedural & Reader's perspective & 29 \\
Cultural & Writing process & 60 \\
& Critical thinking & 76 \\
& Creativity & 83 \\
& Aesthetics & 19 \\
& Personal expression & 64 \\
\hline
\end{tabular}

Note. Type of item: multiple choice, multiple answer (Item 2 in Table C1). 
Table C3. Teachers' beliefs about writing instruction: Self-Efficacy beliefs.

\begin{tabular}{|c|c|c|c|c|}
\hline Level & Paradigm /Dimension & & Item & Percentage \\
\hline \multirow[t]{8}{*}{ Domain specific } & Linguistic & Micro & Helping my students improve their written formulation skills & 82 \\
\hline & & Macro & Helping my students organize their writing texts & 78 \\
\hline & Communicative & & Helping my students consider others' perspective while writing & 32 \\
\hline & Procedural & & Helping my students manage their writing process & 70 \\
\hline & Cultural & & Helping my students write aesthetically & 22 \\
\hline & & & Helping my students develop their creativity while they write & 65 \\
\hline & & & Helping my students develop their ideas while their write & 74 \\
\hline & & & $\begin{array}{l}\text { Helping my students develop their critical thinking while they } \\
\text { write }\end{array}$ & 34 \\
\hline \multirow[t]{13}{*}{ Generic } & Subject & & Language knowledge & 86 \\
\hline & & & Literature knowledge & 64 \\
\hline & & & Communication knowledge & 61 \\
\hline & Pedagogical & & Writing instruction & 51 \\
\hline & & & Reading instruction & 58 \\
\hline & & & Oral communication instruction & 34 \\
\hline & & & Pedagogic planning and methods & 63 \\
\hline & Socio-educational & & Adaptation to my students' various needs & 56 \\
\hline & & & Collaborative writing & 37 \\
\hline & & & Discipline management & 69 \\
\hline & & & Students' motivation & 70 \\
\hline & & & Students' affective support & 51 \\
\hline & & & Students' tutoring & 50 \\
\hline
\end{tabular}

Note. Type of item: multiple choice, multiple answer (Item 2 in Table C1). 
413 | JOURNAL OF WRITING RESEARCH

\section{Appendix D: The relation between teachers' domain specific and generic beliefs}

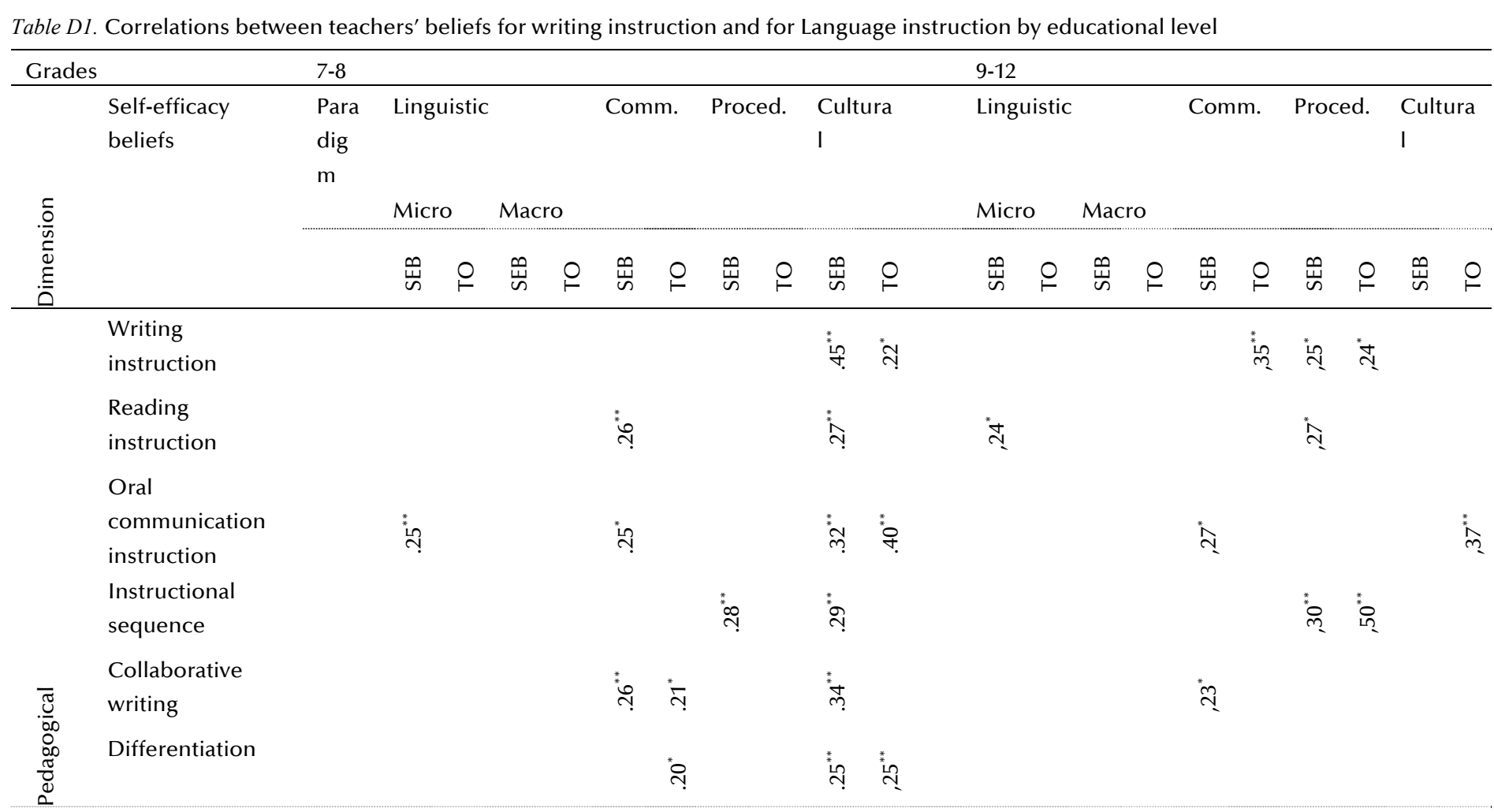


FLORES-FERRÉS · UNDERSTANDING WRITING CURRICULUM INNOVATION IN CHILE | 414

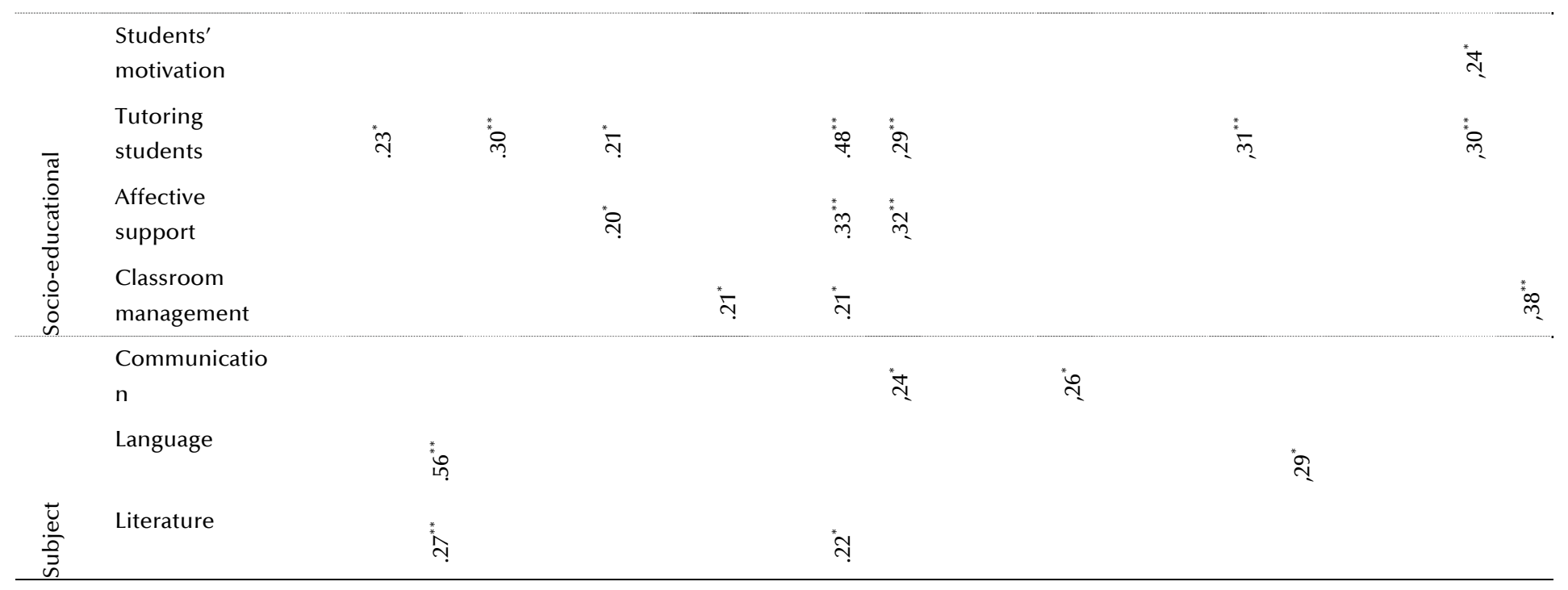

${ }^{*}$ Correlation is significant at the 0.05 level (2-tailed); ${ }^{* *}$ Correlation is significant at the 0.01 level (2-tailed)

Note. Comm.= Communicative; Proced.= Procedural $; \mathrm{TO}=$ Theoretical beliefs; $\mathrm{SEB}=$ Self-efficacy beliefs; IP = Instructional practices; FP = Feedback practices. 